\title{
The genus Chamaecrista Moench in a fragment of the Ecological Station Raso da Catarina, Bahia, Brazil
}

\author{
Cláudia Letícia de Souza Barros Correia ${ }^{1}$ \& Adilva de Souza Conceição ${ }^{1 *}$ \\ ${ }^{1}$ Universidade do Estado da Bahia, Departamento de Educação, Programa de Pós-Graduação em Biodiversidade \\ Vegetal, Campus VIII, Paulo Afonso, BA, Brazil \\ *Corresponding author: Adilva de Souza Conceição, e-mail: adilva.souza@gmail.com
}

CORREIA, C.L.S.B., CONCEIÇÃO, A.S. The genus Chamaecrista Moench in a fragment of the Ecological Station Raso da Catarina, Bahia, Brazil. Biota Neotropica. 17(2): e20160225. http://dx.doi.org/10.1590/1676-0611-BN-2016-0225

\begin{abstract}
Chamaecrista has a Pantropical distribution, with some occurrences in Australia and temperate areas, and includes about 330 species, of which 266 occur in the Americas. The genus is represented in Brazil by 256 species, of which 97 are cited for the northeast Region. The Ecological Station Raso da Catarina (ESRC) is one of the largest areas of protected Caatinga and occupies about $105,282.00$ ha., delimited by the coordinates $09^{\circ} 39^{\prime} 0.30^{\prime \prime}$ to $09^{\circ} 50^{\prime} 98.2^{\prime \prime} \mathrm{S}$ and $38^{\circ} 26^{\prime} 57.5^{\prime \prime}$ to $38^{\circ} 29^{\prime} 32.6^{\prime \prime} \mathrm{W}$. The floristic survey of Chamaecrista in the ESRC included analysis of specimens collected from March 2010 and October 2011. The analyses were supplemented with dried collections from the following herbaria: ALCB, EAC, HRB, HUEFS and MBM. The genus is represented in the study area by ten taxa. The most representative taxa in the area were Chamaecrista repens (Vogel) H.S.Irwin \& Barneby var. multijuga (Benth.) H.S.Irwin \& Barneby, C. brevicalyx (Benth.) H.S.Irwin \& Barneby var. brevicalyx, C. belemii (H.S.Irwin \& Barneby) H.S.Irwin \& Barneby var. belemii, wich are directly related to sandy soils common in the region. The taxonomic treatment includes a key for the identification, descriptions, illustrations, photos, data geographical distribution, reproductive phenology and comments about the taxa.
\end{abstract}

Keywords: floristics, taxonomy, semiarid, Caatinga, diversity.

\section{O gênero Chamaecrista Moench em um fragmento da Estação Ecológica Raso da Catarina, Bahia, Brasil}

\begin{abstract}
Resumo: Chamaecrista possui uma distribuição Pantropical, com algumas ocorrências na Austrália e em áreas temperadas, inclui cerca de 330 espécies, das quais 266 ocorrem nas Américas. O gênero está representado no Brasil por 256 espécies, das quais 97 são citadas para a região nordeste. A Estação Ecológica Raso da Catarina (ECRC) é uma das maiores áreas protegidas de Caatinga e ocupa cerca de 105.282.00 ha., delimitada pelas coordenadas 09³9'0,30” a 0950'98,2" S e 38²6’57,5” a 38²9’32,6” W. O levantamento florístico de Chamaecrista na ECRC incluiu análises de espécimes coletados de março 2010 a outubro de 2011. As análises foram complementadas com coleções dos seguintes herbários: ALCB, EAC, HRB, HUEFS e MBM. O gênero está representado na área de estudo por dez táxons, onde os mais representativos foram: Chamaecrista repens (Vogel) H.S.Irwin \& Barneby var. multijuga (Benth.) H.S.Irwin \& Barneby, C. brevicalyx (Benth.) H.S.Irwin \& Barneby var. brevicalyx, C. belemii (H.S.Irwin \& Barneby) H.S.Irwin \& Barneby var. belemii, estando diretamente relacionados com solos arenosos comuns na região. O tratamento taxonômico inclui uma chave para a identificação, descrições, ilustrações, fotografias, dados de distribuição geográfica, fenologia reprodutiva e comentários sobre os táxons.
\end{abstract}

Palavras-chave: florística, taxonomia, semiárido, Caatinga, diversidade.

\section{Introduction}

Chamaecrista was established by Moench (1794), segregating it from Cassia s.l. (Irwin \& Barneby 1982). It is one of the largest genera of the subfamily Caesalpinioideae and the largest of the subtribe Cassiinae (Lewis 2005). It has a Pantropical distribution, with some occurrences in Australia and temperate areas. The genus includes approximately 330 species, of which 266 occur in the Americas (Irwin \& Barneby 1982, Lewis 2005).
In Brazil, the genus is represented by about 256 species, of which 97 are cited for the Northeast Region. Bahia is considered to be the state with the third greatest number of taxa of Chamaecrista with 91 species. The center of their diversity is in campos rupestres (rocky fields) (Lewis 1987, Conceição et al. 2001, Zappi et al. 2003, Souza \& Bortoluzzi 2016). In Caatinga twenty-nine species were recorded for Chamaecrista (Queiroz 2009).

Chamaecrista is mainly characterized by presence of two alternate bracteoles on the pedicel of the flowers, convex extrafloral nectaries 
and spiraled elastically dehiscent fruits. According to Irwin \& Barneby (1982), the genus includes six sections. All phylogenetic studies based on morphological and molecular data supported the monophyly of Chamaecrista (Conceição et al. 2009, Rando et al. 2016). However, with regard to infrageneric classification, the study of Conceição et al. (2009) showed that only two of the six sections recognized by Irwin \& Barneby (1982) are monophyletic. Rando et al. (2016) supports the monophyly of $C$. ser. Coriaceae, suggesting $C$. ser. Flexuosae as the sister group of this clade.

The more comprehensive taxonomic treatments for Chamaecrista was carried by Vogel (1837), Bentham (1870, 1871), Greene (1897), Pollard (1902), Britton \& Rose (1930), Irwin \& Rogers (1967), Irwin (1964) and Irwin \& Barneby $(1977,1978,1981,1982)$, Fernandes \& Nunes (2005). The last three studies comprised the most relevant treatments of the genus, with the recognition of sections and series, and the descriptions of new species and infraspecific taxa, including additional information on ecology and geographic distribution.

The main contributions on taxonomy of the referred genus in Brazil are generally about local floristic surveys, publication of new species or re-establishment, which showed the great diversity of the genus to Brazil, such as the works conducted by Harley \& Simmons (1986), Lewis (1987), Barneby (1994), Costa (1996), Conceição et al. (2001, 2003), Camargo \& Miotto (2004), Hervencio \& Queiroz (2004), Conceição (2006), Bortoluzzi \& Miotto (2007), Cardoso \& Queiroz (2007), Queiroz (2009), Queiroz \& Loiola (2009), Rando (2009), Rando \& Pirani (2012), Dantas \& Silva (2013), Rando et al. (2013a, b), Souza \& Silva (2014, 2015), Silva \& Souza (2015), Souza et al. (2015), Barbosa et al. (2016), Cota et al. (2016).

Despite the existence of studies about Chamaecrista for the semiarid of northeastern Brazil, regional works for the state of Bahia are scarce, especially those that include keys of identification and descriptions. Given the importance of Chamaecrista in the Caatinga vegetation, this work had as a goal to carry out the survey of the species of the genus in the Ecological Station Raso da Catarina (ESRC) in order to contribute to knowledge about the flora of the semiarid region of Bahia as well as to support the development of the ESRC management plan.

\section{Material and Methods}

The Raso da Catarina Ecoregion comprises $30.800 \mathrm{~km}^{2}$ and is one of the eight Ecoregions recognized for the Caatinga and includes units of conservation. In the North-south direction it is narrow and elongated. In the North, West and East directions it is limited to the southern hinterland depression. The northeastern portion has limits with the Borborema Plateau and the southern part of the Bahia hinterland, in the Zona da Mata. The Ecoregion is a basin with soils that are very sandy, deep and little fertile. Its relief is very flat, but with canyons in the western part (formed by sandstone outcrops). The altitudes above sea level vary from 400 to $600 \mathrm{~m}$ in the southern part (Bahia) and from 350 to $700 \mathrm{~m}$ in the northern part (Jatobá basin, Pernambuco). In the southern part (Bahia) most of the soils are composed of sand (deep, excessively drained, acid and very low fertility) and oxisol (deep, well drained, acid and low fertility) whereas in the northern part (Pernambuco) sands soils prevail. There exists little surface water in the region except in the areas of the canyons. The predominant vegetation is the sandy, bushy Caatinga, very dense and less thorny than the Caatinga of crystalline soils (Velloso et al. 2002).

The Ecological Station Raso da Catarina (ESRC, Figure 1) is one of the protected areas of the Raso da Catarina Ecoregion. It is one of the

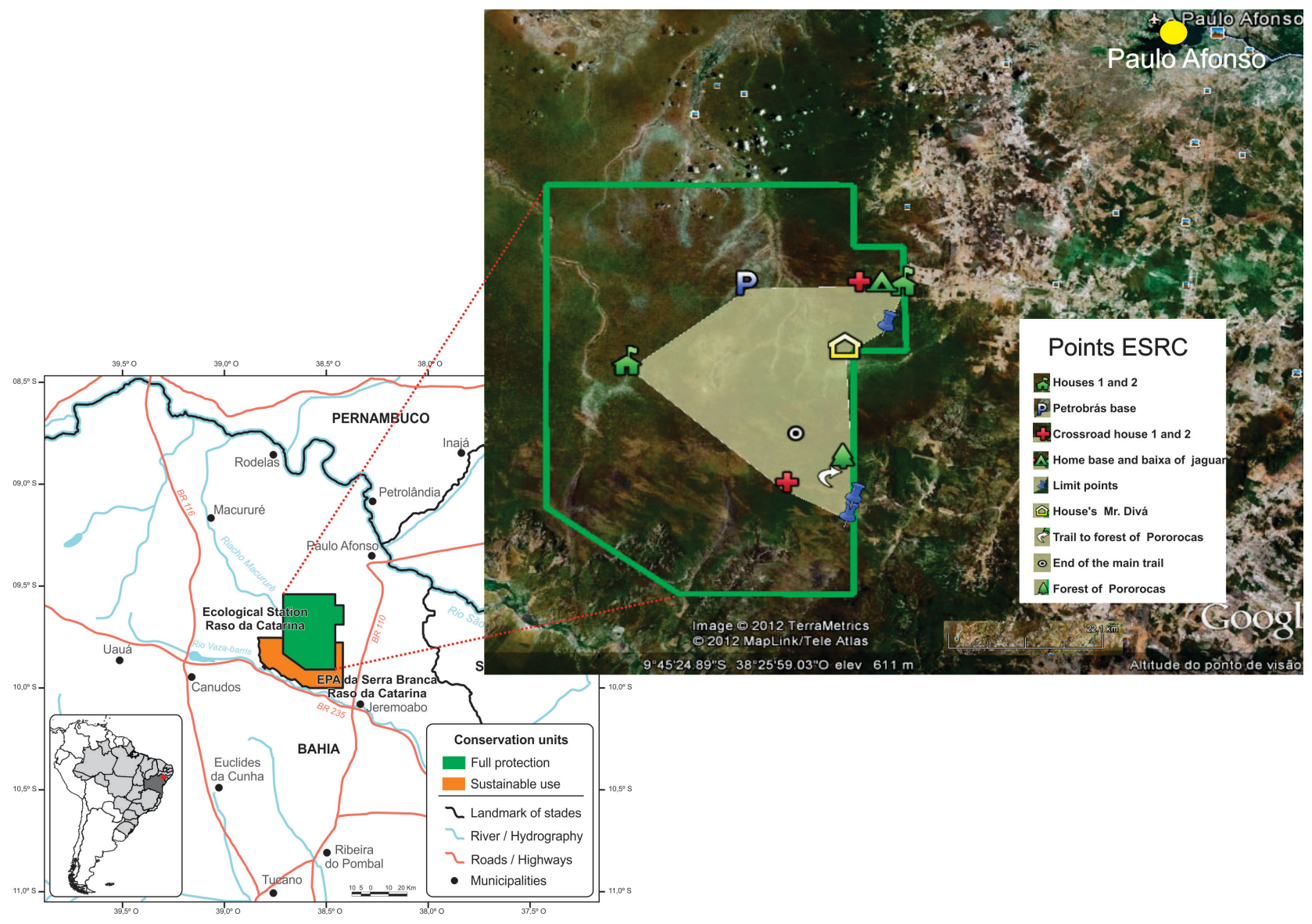

Figure 1. Location of the fragment studied in the Raso da Catarina Ecological Station (Varjão et al. 2013, modified). 
largest areas of protected Caatinga and occupies about 105,282.00 ha., delimited by the coordinates $09^{\circ} 39^{\prime} 0.30^{\prime \prime}$ to $09^{\circ} 50^{\prime} 98.2^{\prime \prime} \mathrm{S}$ and $38^{\circ} 26^{\prime} 57.5^{\prime \prime}$ to $38^{\circ} 29^{\prime} 32.6^{\prime \prime} \mathrm{W}$, limited to the North with the Pankararé aldeia, to the east with the municipalities of Rodelas and Canudos, to the South with the municipality of Jeremoabo and West with the municipalities of Paulo Afonso and Jeremoabo. The climate of the ESRC is semiarid with average rainfalls of $500 \mathrm{~mm} /$ year and annual temperature is approximately $23^{\circ} \mathrm{C}$ (Szabo et al. 2007). The soils are generally sandy deep and very fertile relief plan with sandstone formations (Velloso et al. 2002).

The study was based on fieldwork carried out in the period between March 2010 and October 2011, besides information complemented by the analysis of species deposited in the herbaria: ALCB, EAC, HRB, HUEFS and MBM, acronyms according to Thiers 2016 (continuously updated). The field collections and observations were performed during random walks exploring most of the study area. Herborization and material processing followed the methodology by Fosberg \& Sachet (1965) and Mori et al. (1989), where fertile material was collected with flowers and/or fruit. Observations were made about the distribution of the species and the type of soil (Tricart 1972, Sampaio 1995). The specimens were deposited in the herbarium of the State University of Bahia (HUNEB - Collection Paulo Afonso) and the duplicates were sent to the main herbaria in the state of Bahia.

The identifications were made based mainly on specialized bibliographies (e.g., Irwin \& Barneby 1978, 1982 and Queiroz 2009), protologues, photos of type collections and consulting of the collections in the herbaria that were visited. For the taxonomic descriptions, the terminologies proposed by Radford et al. (1974), Irwin \& Barneby (1978, 1982), Ribeiro et al. (1999), Harris \& Harris (2001) and Gonçalves \& Lorenzi (2011) were adopted. The taxonomic treatment includes a key for the identification of taxa, descriptions, illustrations, and data of the geographical distribution and reproductive phenology of the species.

\section{Results and Discussion}

Chamaecrista Moench, Meth. pl. hort. Bot. Marburg.: 272, 1794. Lectotype (designated by Irwin, 1964): sect. Chamaecrista, C. nictitans (L.) Moench.

Herbs, shrubs or subshrubs, erect, prostrate, sarmentose, decumbent or procumbent, little or profusely brancheds; branches cylindrical, rare quadrangular, straight, sometimes tortuous, rare fractiflex. Leaves green, alternating, paripinnate, 2-multifoliolate; extrafloral nectaries present or absent, when present with concave secretory surface, sessile and discoid or stipitate and caliciform, located on the petiole, rarely on the rachis and pairs of leaflets. Inflorescence racemose, elongated, or reduced in fascicles axillary or supra-axillary, with few flowers or reduced to a single flower; bracteoles 2, alternating or subopposite, than in different positions on the pedicel; flowers pentamerous, asymmetric; sepals free, the internal larger the ones; petals free, yellow to orange, heteromorphic, with a differentiated internal abaxial petal (cuculus), falcate, spatulate to suborbicular, bent on the stamens, protecting the androecium, stamens 10, homomorphic, arranged at equal length levels or at different levels, anthers dehiscent by apical pore. Legumes elastically dehiscent, oblong, plan-compressed, with valves chartaceous or coriaceous, spiraled after seed release. Seeds compressed, glossy, rhomboid to pyriform, testa dark brown, pitted, pits aligned in vertical rows.

In the Ecological Station Raso da Catarina ten taxa were recorded for genus. Chamaecrista repens (Vogel) H.S.Irwin \& Barneby var. multijuga (Benth.) H.S.Irwin \& Barneby, C. brevicalyx (Benth.) H.S.Irwin \& Barneby var. brevicalyx, C. belemii (H.S.Irwin \& Barneby) H.S.Irwin \& Barneby var. belemii, were taxa predominant in the studied area, being directly related to sandy soils common in the region.

\section{Identification key for the representatives of the genus Chamaecrista}

1. Presence of tector trichomes only; extrafloral nectaries present; leaves with 2-21 pairs of leaflets; inflorescences axillary, supra-axillary or reduced to only flower.

2. Leaves with $2-8$ pairs of leaflets; inflorescences axillary, reduced to a single flower.

3. Leaves with two pairs of leaflets, venation paralelinervous; sepals multistriated.....7. Chamaecrista ramosa var. ramosa

3'. Leaves with 4-8 pairs of leaflets, venation palminerveous; sepals striated.

4. Branches quadrangular, fractiflex; stipules acuminate to aristated; leaflets with cuspidate to spinescent apex .9. C. swainsonii

4'. Branches cylindrical, erect; stipules lanceolate to deltoid; leaflets with acuminate to cuspidate apex .. 10. C. tenuisepala

2'. Leaves with 8-21 pairs of leaflets; inflorescences supra-axillary.

5. Extrafloral nectary sessile to shortly stipitate, discoid to caliciform, head less dilated the stipe, located little above the middle of the petiole; midrib excentric, dividing the leaflet in a ratio of $1: 2-2.5$ at the base.

8. C. repens var. multijuga

5'. Extrafloral nectary shortly stipitate, caliciform, head more dialated than the stipe, located next to the middle of the petiole; midrib little excentric dividing the leaflet in a ratio of $1: 1-1.5$ at the base

..6. C. nictitans subsp. disadena var. disadena

1'. Presence of tector and glandular trichomes; extrafloral nectaries absent; leaves with two pairs of leaflets; inflorescence terminal.

6. Herbs procumbent to sarmentose; petiole c. 1.5 times longer than the rachis; flower buds acute ..5. C. carobinha

6'. Shrubs to subshrubs erect or herbs to subshrubs procumbent; petiole c. 1.5-7 times longer than the rachis; flower buds rounded.

7. Petiole c. 7 times longer than the rachis; leaflets glabrous.

8. Epidermis on the young branches pale to whitish; leaflets ovate to suborbicular, 9-35 mm long.; flowers c. $3 \mathrm{~cm}$. diam................ 4. C. brevicalyx var. brevicalyx

8'. Epidermis on the young branches green; leaflets ovate to obovate, 4-11 mm long.; flowers c. $1 \mathrm{~cm}$ diam. 2. C. amiciella

7'. Petiole 1.5-5 longer than the rachis; leaflets glabrous to pilose.

9. Leaflets ovate to obovate, apex emarginate to rounded; petiole c. 1.5 times longer than the rachis 3. C. belemii var. belemii

9'. Leaflets elliptic to obelliptic, apex acute to emarginate; petiole c. 3-5 times longer than the rachis............................................... C. acosmifolia

1. Chamaecrista acosmifolia (Benth.) H.S.Irwin \& Barneby var. acosmifolia, Mem. New York Bot. Gard. 35(2): 660. 1982. Figures 2a; 3a-k 

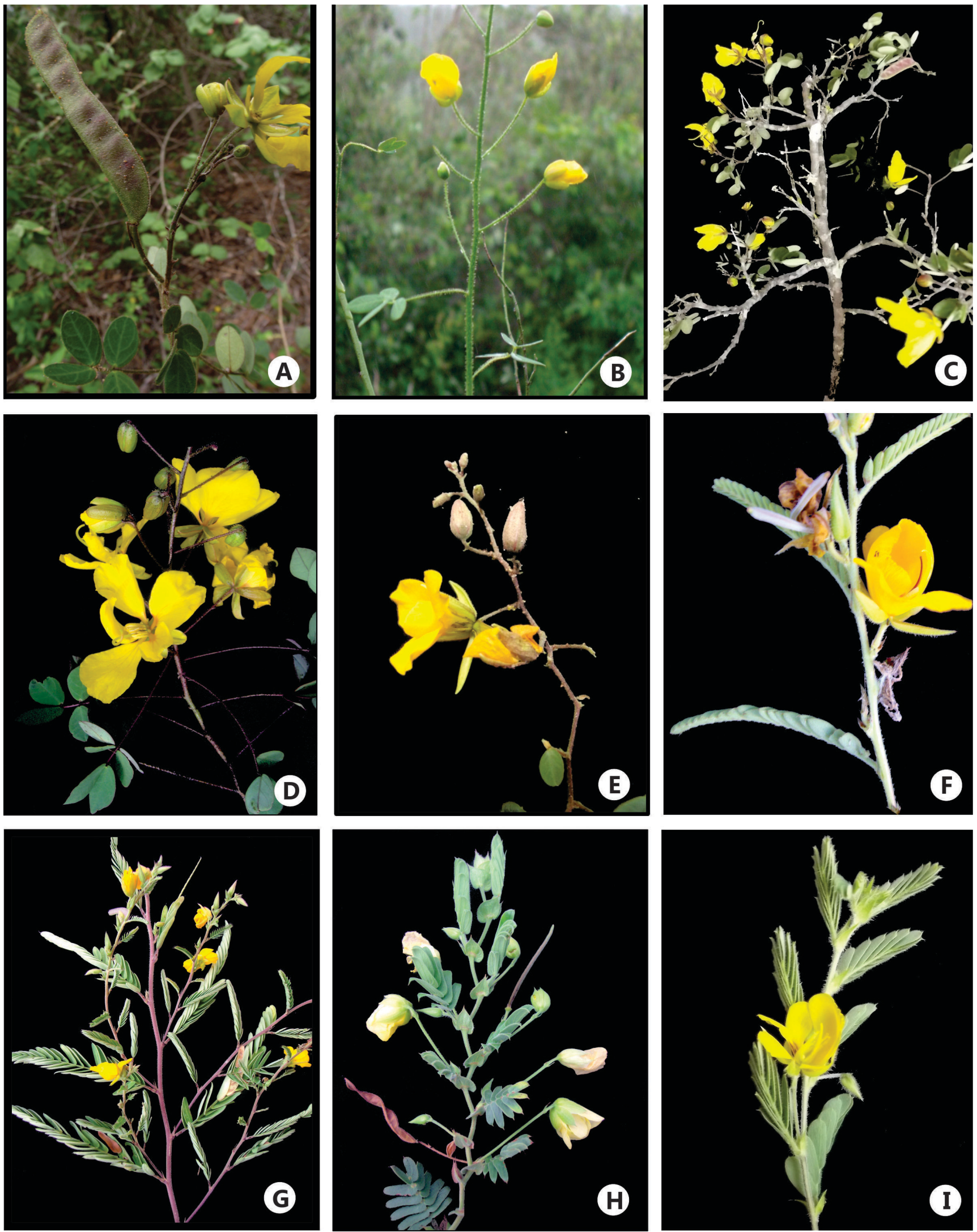

Figure 2. Representative of Chamaecrista in the ESRC: a) Chamaecrista acosmifolia (Benth.) H.S.Irwin \& Barneby var. acosmifolia; b) C. amiciella (H.S.Irwin \& Barneby) H.S.Irwin \& Barneby; c) C. belemii (H.S.Irwin \& Barneby) H.S.Irwin \& Barneby var. belemii; d) C. brevicalyx (Benth.) H.S.Irwin \& Barneby var. brevicalyx e) C. carobinha (H.S.Irwin \& Barneby) H.S.Irwin \& Barneby; f) C. nictitans Moench subsp. disadena (Steud.) H.S.Irwin \& Barneby var. disadena; g) C. repens (Vogel) H.S.Irwin \& Barneby var. multijuga (Benth.) H.S.Irwin \& Barneby; h) Chamaecrista swainsonii (Benth) H.S.Irwin \& Barneby; i) C. tenuisepala (Benth.) H.S.Irwin \& Barneby. Photos by C.L.S.B.Correia. 

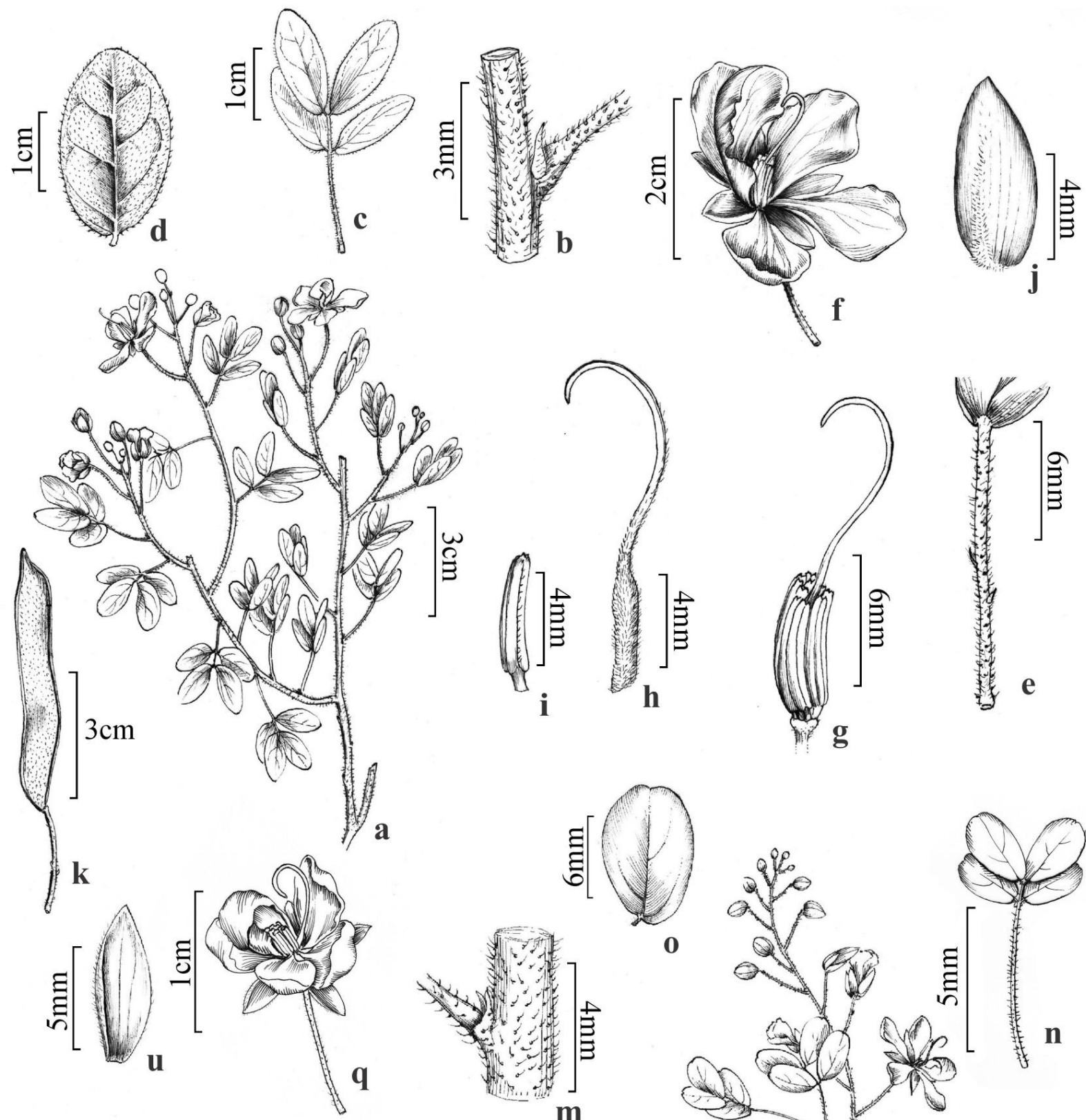
Shrubs erect, branched until $3 \mathrm{~m}$ tall; branches cylindrical,erect, epidermis vinaceous on the young branches, discretely exfoliating and brown on the old branches. Indumentum glabrescent, constituted of trichomes glandular and tector, thin, yellow to dark castaneous, rigid, erect, sparse, c. $1 \mathrm{~mm}$ long, distributed on the branches, petioles, inflorescence axis, pedicels, buds and sepals. Stipules vinaceous to brown, filiform, obsolete, $0.5-1 \times$ c. $0.5 \mathrm{~mm}$, caducous. Leaves $2.2-6.1 \mathrm{~cm}$ long; pulvinus brown, sparsely pilose, $1-2 \mathrm{~mm}$ diam.; petiole $10-22 \mathrm{~mm}$ long, c. 3-5 times longer than the rachis; without extrafloral nectaries; rachis $2-7 \mathrm{~mm}$ long; leaflets discolorous, 2 pairs, chartaceous, pilose, 15-25 $\times 7-14 \mathrm{~mm}$, elliptic to obelliptic, apex acute to emarginate, base rounded and asymmetric, venation penninervous. Inflorescences racemose grouped in panicles, terminal, 6-34 flowers; inflorescence axis $5-10 \mathrm{~cm}$ long; bracts vinaceous to brown, lanceolate, $1.5-2 \times 0.5-1 \mathrm{~mm}$; pedicel 7-24 mm long; bracteoles green vinaceous, lanceolate, $0.5-1 \times 0.5 \mathrm{~mm}$, located on the middle of pedicel. Buds green-vinaceous, rounded, 1-5 mm long. Flowers c. $2.5 \mathrm{~cm}$ diam.; sepals green glaucous to yellowish-green, ovate to oblong, abaxial surface pilose, striated, $6-9 \times 2.5-5.5 \mathrm{~mm}$; petals golden yellow, two external, obovate to orbicular, $12-14 \times 8-10 \mathrm{~mm}$, two internal, oblong to obelliptic, $8-15 \times 3-9 \mathrm{~mm}$, cuculus falcate, bent around the stamens, $10-13 \times 18.5-20 \mathrm{~mm}$; stamens yellow, 3-6 mm long; ovary green glaucous to yellowish, tomentose, 2-6 mm long; style yellow, 8-11 mm long. Legumes oblong, linear, green to green-vinaceous when young, mature brown, 12-64 × 2-9 mm; valves coriaceous, setulose. Seeds ellipsoid when young, quadrangular to rhomboid when mature, brown to vinaceous, glossy, pitted at base, $4-6 \times$ c. $4 \mathrm{~mm}$.

Material examined: BRAZIL, BAHIA: Paulo Afonso, Estação Ecológica Raso da Catarina, Trilha sentido Baixa da onça, 0952’21” S

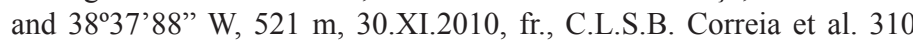
(HUNEB); Trilha sentido Pedra da janela, $09^{\circ} 39^{\prime} 55^{\prime \prime} \mathrm{S}$ and $38^{\circ} 28^{\prime} 02^{\prime \prime} \mathrm{W}$, 570 m, 30.XII.2010, fl.; fr., C.L.S.B. Correia et al. 359 (HUNEB); Baixa da onça, 0952'21" S and 38³7'88” W, 521 m, 24.III.2010, fl.; fr., C.L.S.B. Correia et al. 110 (HUNEB).

Chamaecrista acosmifolia is a Brazilian endemic species having been recorded to Minas Gerais, Goiás and Mato Grosso, where it occurs in Caatinga and Cerrado at altitudes of 500-600 m (Irwin \& Barneby 1978, Queiroz 2009). Irwin \& Barneby (1978) recognized three varieties for the species, two of which occur in the Caatinga: C. acosmifolia (Benth.) H.S.Irwin \& Barneby var. euryloba (H.S.Irwin \& Barneby) H.S.Irwin \& Barneby, with records only for Bahia, and C. acosmifolia (Benth.) H.S.Irwin \& Barneby var. acosmifolia, distributed in Bahia, Piauí and Maranhão. In the study area, only the acosmifolia variety was catalogued; it is rare, flowers and fruits in November, December and March, and occurs in ecotonal areas with rocky soil at altitudes of 521-570 m.

In the study area, the taxon can be recognized by two pairs of elliptic to obelliptic leaflets, but can be confused with $C$. belemii var. belemii because both have leaves with two pairs of leaflets and racemose terminal inflorescences. However, the two taxa can be differentiated by size and shape of their leaflets $(6-25 \times 4-13 \mathrm{~mm}$, ovate to obovate in C. belemii var. belemii vs. $15-25 \times 7-14 \mathrm{~mm}$, elliptic to obelliptic in C. acosmifolia var. acosmifolia) and size of their fruits (6-38 mm long in C. belemii var. belemii vs.12-64 mm long in C. acosmifolia var. acosmifolia).

2. Chamaecrista amiciella (H.S.Irwin \& Barneby) H.S.Irwin \& Barneby, Mem. New York Bot. Gard. 35(2): 661. 1982. Figures 2b; 31-v

Herbs and subshrubs procumbent, little branched until $1 \mathrm{~m}$ tall; branches cylindrical, erect or tortuous, epidermis green on the young branches, brown on the older branches. Indumentum glabrescent, constituted of trichomes glandular and tector, thin, yellow to dark brown, rigid, erect, sparse, c. $1 \mathrm{~mm}$ long, distributed on the branches, petioles, inflorescence axis, pedicels, buds and sepals. Stipules green to brown, filiform, obsolete, caducous,
$0.5-1 \times$ c. $0.5 \mathrm{~mm}$. Leaves $2.2-4.5 \mathrm{~cm}$ long; pulvinus brown, sparsely pilose, 1-2 mm diam; petiole 7-28 mm long., c. 7 times longer than the rachis; without extrafloral nectaries; rachis 1-4 mm long; leaflets discolorous, 2 pairs, chartaceous, glabrous, ovate to obovate, 4-11 $\times 3-7 \mathrm{~mm}$, apex emarginate to retuse, base rounded, venation penninervous. Inflorescences racemose, terminal, 6-34 flowered, inflorescence axis 4.5-6.7 cm long; bracts vinaceous to castaneous, lanceolate, $1.5-2 \times 0.5-1 \mathrm{~mm}$; pedicel 6-12 mm long; bracteoles green vinaceous, lanceolate, $0.5-1 \times 0.5 \mathrm{~mm}$, located on the upper region of the pedicel. Buds green to green-vinaceous, rounded, 1-7 mm long. Flowers c. $1 \mathrm{~cm}$ diam.; sepals green glaucous to green-yellowish, ovate to oblong, abaxial surface pilose, striated, 4-6 $\times 3-5.5 \mathrm{~mm}$; petals yellow, two external, obovate, 9-11 $\times 4-6 \mathrm{~mm}$, two internal, oblong to obelliptic, $7-9 \times 3-4 \mathrm{~mm}$, cuculus falcate, bent around the stamens, 8-9.5 $\times 9-10 \mathrm{~mm}$; stamens yellow, 2.5-4 mm long; ovary pale green to yellowish, pilose, 1.5-2 mm long; style yellow, 4-6 mm long. Legumes oblong, linear, green when young, mature not seen, 24-27 × 5-6.5 mm, valves chartaceous, setulose. Seeds not seen.

Material examined: BRAZIL, BAHIA: Paulo Afonso, Estação Ecológica Raso da Catarina, Trilha sentido Mata da pororoca, 948'32” S and 38 29'30" W, 584 m, 29.XII.2010, fl., C.L.S.B. Correia et al. 327 (HUNEB); Trilha sentido casa II, vindo da Pororoca, 0949'15" S and 38²9’33” W, 670 m, 14.I.2010, C.L.S.B. Correia et al. 373 (HUNEB); Baixa do Cascavel, 09.VI.11, 0944'08' S and 38 40'56” W, $606 \mathrm{~m}$, C.L.S.B. Correia et al. 489 (HUNEB).

Chamaecrista amiciella is endemic to the Caatinga and has been recorded in southern Ceará, western Paraíba and northern Bahia, where it occurs on sandy soil at altitudes between 150-500 m (Irwin \& Barneby 1978, Queiroz 2009). In the ESRC the species is rare and occurs on sandy soil at altitudes of 580-660 m. It was collected with flowers and fruits in January, December and June.

The size of the leaflets $(4-11 \mathrm{~mm})$ and diameter of the flowers $(\mathrm{ca} .1 \mathrm{~cm})$, distinguish it from other species occurring in the area.

3. Chamaecrista belemii (H.S.Irwin \& Barneby) H.S.Irwin \& Barneby var. belemii, Mem. New York Bot. Gard. 35(2): 644. 1978. Figures 2c; 4a-k

Shrubs erect, profusely branched until $1.5 \mathrm{~m}$ tall; branches cylindrical,erect a tortuous, epidermis brown on the young branches, exfoliating and pale to greyish on the old branches. Indumentum glabrescent, constituted of trichomes glandular and tector, thin, brown to black and little orange to white, flexible, erect, sparse, c. $1.5 \mathrm{~mm}$ long, distributed on the branches, margin of stipules, petioles, pulvinus, rachis, pedicel, buds, sepals, ovary, legumes, rarely occurring on margin of leaflets. Stipules vinaceous to brown, lanceolate, obsolete, $0.5-2 \times 0.5-1 \mathrm{~mm}$, caducous. Leaves $2.2-4.8 \mathrm{~cm}$ long; pulvinus brown, sparsely pilose, c. $1 \mathrm{~mm}$ diam; petiole $7-19 \mathrm{~mm}$ long, c. 1.5 times longer than the rachis; without extrafloral nectaries; rachis 4-8 mm long; leaflets discolorous, 2 pairs, chartaceous, glabrous to sparsely pilose, ovate to obovate, 6-25 $\times 4-13 \mathrm{~mm}$, apex emarginate to rounded, base asymmetrical, venation penninervous. Inflorescences racemose, terminal, sometimes grouped in panicles; $2-8$ flowered, inflorescence axis 2-4.5 cm long; bracts green, lanceolate, 1-1,5 mm long; pedicel 4-20 mm long; bracteoles vinaceous, lanceolate to ovate, $0.5-1.5 \times$ c. $0.5 \mathrm{~mm}$, located along the pedicel. Buds green, rounded, 3-7 mm long. Flowers c. $3 \mathrm{~cm}$ diam; sepals green, ovate to obovate, abaxial surface pilose, striated, 7-10 $\times 3-6 \mathrm{~mm}$; petals golden yellow, two external, obovate to orbicular, 19-23 × 16-18 mm, two internal, obovate, $15-17 \times 11-12 \mathrm{~mm}$, cuculus falcate, bent around the stamens, c. $18 \times 11-13 \mathrm{~mm}$; stamens yellow, 5-7 mm long; ovary green glaucous to yellowish-green; style yellow, 5-9 mm long. Legumes oblong, linear, green when young vinaceous, brown when mature, $6-38 \times 3-8 \mathrm{~mm}$, valves coriaceous, puberule to setulose. Seeds quadrangular to rhomboid, brown to black, glossy and pitted, 3-4 × 1-3 mm. 


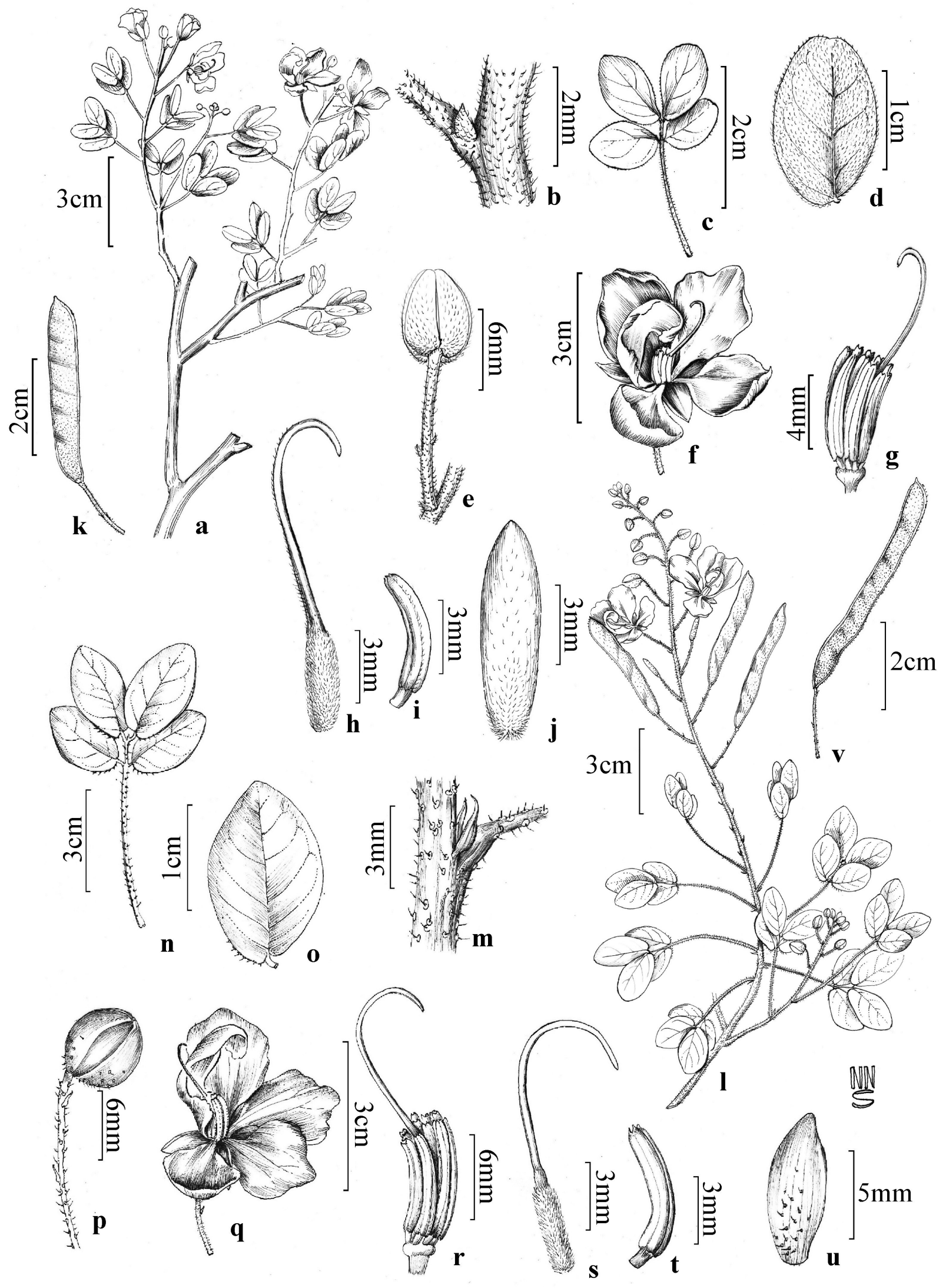

Figure 4. a-k) Chamaecrista belemii var. belemii: a) flowering branch; b) stipule; c) leaf; d) leaflet; e) bud and bracteoles; f) flower; g) androecium and gynoecium; h) pistil; i) stamen; j) sepal; k) fruit. 1-v) Chamaecrista brevicalyx var. brevicalyx: 1) flowering branch; m) stipule; n) leaf; o) leaflet; p) bud and bracteoles; q) flower; r) androecium and gynoecium; s) pistil; t) stamen; u) sepal; v) fruit. a-k from C.L.S.B. Correia 491; 1-v from C.L.S.B. Correia 571. 
Material examined: BRAZIL, BAHIA: Paulo Afonso, Estação Ecológica

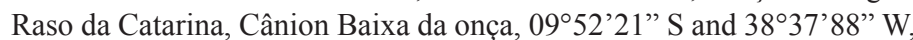
521 m, 24.III.2010, fl., C.L.S.B. Correia et al. 112 (HUNEB); Trilha do pau preto, sentido casa abandonada, $09^{\circ} 41^{\prime} 41^{\prime \prime} \mathrm{S}$ and $38^{\circ} 34^{\prime} 56^{\prime \prime} \mathrm{W}$, 616 m, 18.V.2010, fr., A.A.S. Lopes et al. 933 (HUNEB); Cânion Baixa da onça, 0952'21' S and 38 37'88” W, 521 m, 30.VI.2010, fl., C.L.S.B. Correia et al. 131 (HUNEB); 09.VI.2011, fl., C.L.S.B. Correia et al. 491 (HUNEB); 01.IX.2011, fl.; fr., C.L.S.B. Correia et al. 554 (HUNEB); 27.IX.2011, fr., R.R. Varjão et al. 155 (HUNEB); Trilha ao lado da casa sede, sentido curral, $09^{\circ} 39.84^{\prime \prime}$ S and $38^{\circ} 28^{\prime} 06^{\prime}$ 'W, 592 m, 28.X.2010, fl., C.L.S.B. Correia et al. 323 (HUNEB); 23.XI.2010, fl., C.L.S.B. Correia et al. 267 (HUNEB); 23.XI.2010, fl., C.L.S.B. Correia et al. 293 (HUNEB); 26.VII.2011, fr., C.L.S.B. Correia et al. 511 (HUNEB); Trilha sentido Baixa da onça, 09 52 ' $21^{\prime \prime} \mathrm{S}$ and $38^{\circ} 37^{\prime} 88^{\prime \prime} \mathrm{W}, 521 \mathrm{~m}, 30$.XI.2010, fr., C.L.S.B. Correia et al. 311 (HUNEB); 30.XI.2010, fl., C.L.S.B. Correia et al. 313 (HUNEB); 09.VI.2011, fl., C.L.S.B. Correia et al. 318 (HUNEB); Trilha

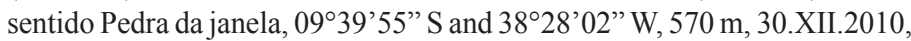
fl., C.L.S.B. Correia et al. 357 (HUNEB).

The taxon is endemic to the Caatinga and has been recorded for the states of Bahia, Sergipe and Pernambuco on sandy soils at altitudes of 200 to $600 \mathrm{~m}$ (Queiroz 2009). Two varieties are recognized, both of which occur in the Caatinga, but only the belemii variety occurs in the study area. The taxon is very common in the ESRC, occurring in areas of shrubby to sub-shrubby Caatinga on sandy to rocky soil at ca. $616 \mathrm{~m}$. It flowers from March to July and September to December, and fruits from May to September and in December.

Chamaecrista belemii var. belemii can be recognized in the area as a profusely branched shrub with the branches being generally tortuous and woody, epidermis pale and exfoliate on the older branches and leaves with two pairs of ovate to obovate leaflets. In the study area the taxon can be confused with C. acosmifolia (see comments in C. acosmifolia).

4. Chamaecrista brevicalyx (Benth.) H.S.Irwin \& Barneby var. brevicalyx, Mem. New York Bot. Gard. 35(2): 660. 1982. Figures 2d; 41-v

Shrubs to subshrubs erect, branched until $2.5 \mathrm{~m}$ tall; branches cylindrical,erect, epidermis pale to whitish on the young branches, exfoliating, brown on the old branches. Indumentum hispid-papillose, constituted of trichomes glandular and tector, thin and thick, colour less to whitish or brown to black, erect, sparse, c. $0.5 \mathrm{~mm}$ long, distributed on the branches, pulvinus, petiole, margin of leaflets, stipules, bracts, bracteoles, pedicel, buds and sepals. Stipules green vinaceous to brown, filiform, obsolete, $1-3 \times 0.5-1 \mathrm{~mm}$ long, caducous. Leaves $3.2-9.7 \mathrm{~cm}$ long; pulvinus black, glabrous, $1-1.5 \mathrm{~mm}$ diam.; petiole $21-56 \mathrm{~mm}$ long, c. 7 times longer than the rachis; without extrafloral nectaries; rachis 3-8 mm long; leaflets discolorous, 2 pairs, chartaceous to membranous, glabrous, ovate to suborbicular, 9-35 × 4-21 mm, apex acute to emarginate, base cuneate to cordate, venation penninervous. Inflorescences racemose, terminal, long, 12-26 flowered; inflorescences axis 4-21 cm long; bracts vinaceous, ovate to deltoid, $1-4 \times 1-1.5 \mathrm{~mm}$; pedicel 4-24 mm long; bracteoles vinaceous, ovate to deltoid, $1-3 \times 0.5-1 \mathrm{~mm}$, located near the receptacle. Buds vinaceous to yellowish, rounded, 2-11 mm long. Flowers c. $3 \mathrm{~cm}$ diam; sepals yellow to yellowish-green, lanceolate, abaxial surface sparsely pilose, striated, 9-10 $\times 4-6 \mathrm{~mm}$; petals yellow, two external and two internal, obovate, $12-16 \times 5-8 \mathrm{~mm}$, cuculus spatulate to suborbicular, bent around the stamens, $18-22 \times 8-11 \mathrm{~mm}$; stamens yellow, 5-9 mm long; ovary green glaucous to yellowish-green, tomentose, $4-5 \mathrm{~mm}$ long; style yellow, 12-16 mm long. Legumes oblong, linear, when young green to vinaceous, brown when mature, $35-63 \times 5-7 \mathrm{~mm}$, valves chartaceous, pubescent to setulose. Seeds ellipsoids young, rhomboid to trapezoids when mature, brown to black, glossy and pitted, 5-6 $\times 3-4 \mathrm{~mm}$.
Material examined: BRAZIL, BAHIA: Paulo Afonso, Estação Ecológica Raso da Catarina, Trilha da Mata da Pororoca, $09^{\circ} 48^{\prime} 72^{\prime}$ S and $38^{\circ} 29^{\prime} 51$ ' W, 698 m, 25.X.2010, fl., C.L.S.B. Correia et al. 236 (HUNEB); 04.IV.2011, fl., C.L.S.B. Correia et al. 427 (HUNEB); Trilha sentido Mata da Pororoca, 0948'32" S and 38'29'30" W, 584 m, 24.XI.2010, fl.; fr., C.L.S.B. Correia et al. 296 (HUNEB); Trilha principal depois da Mata da Pororoca sentido matinha, 09³9'58' S and 38 $27^{\prime} 61^{\prime \prime} \mathrm{W}, 635 \mathrm{~m}$, 22.XI.2010, fl., C.L.S.B. Correia et al. 255 (HUNEB); Trilha sentido casa II do ICMbio, 0949'15" S and 38²9’33” W, 667 m, 24.XI.2010, fr., C.L.S.B. Correia et al. 276 (HUNEB); Trilha sentido Mata da Pororoca, depois da $1^{\circ}$ encruzilhada, vindo da casa I do ICMbio, 9०47'57' $\mathrm{S}$ and 38²9’30" W, 584 m, 29.XII.2010, fl., C.L.S.B. Correia et al. 364 (HUNEB); Trilha sentido Mata da Pororoca, 0948'32" S and 38 29'30" W 584 m, 24.III.2010, fl., C.L.S.B. Correia et al. 98 (HUNEB); 24.III.2010, fl., C.L.S.B. Correia et al. 100 (HUNEB); 19.V.2010, fr., M.V.V. Romão, et al. 619 (HUNEB); 29.XII.2010, fl., C.L.S.B. Correia et al. 338 (HUNEB); Trilha sentido casa II do ICMbio, 0949'15" S and 38 29'33" W, $667 \mathrm{~m}$ 24.XI.2010, fl., C.L.S.B. Correia et al. 282 (HUNEB); Trilha sentido Mata da Pororoca, vindo da casa I do ICMbio, 945'29” S and 38 29'29” W, 584 m, 04.II.2011, fl., C.L.S.B. Correia et al. 382 (HUNEB); 04.II.2011, fl., C.L.S.B. Correia et al. 385 (HUNEB); 04.II.2011, fl., C.L.S.B. Correia et al. 386 (HUNEB); 08.IX.2011, fl., C.L.S.B. Correia et al. 569 (HUNEB); 25.X.2011, fl.; fr., C.L.S.B. Correia et al. 598 (HUNEB); Trilha sentido casa II do ICMbio, vindo da Mata da Pororoca, 0949'14" S and 38²9'31"W, 670 m,14.I.2011, fl., C.L.S.B. Correia et al. 374 (HUNEB); 25.III.2011, fl., C.L.S.B. Correia et al. 393 (HUNEB); 25.III.2011, fl., C.L.S.B. Correia et al. 398 (HUNEB); 04.V.2011, fl., C.L.S.B. Correia et al. 458 (HUNEB); 04.V.2011, fr., C.L.S.B. Correia et al. 450 (HUNEB); Trilha sentido sul da Estação ca. $10 \mathrm{~km}$ da Mata da Pororoca, 0943'18" S and $38^{\circ} 29^{\prime} 30^{\prime \prime}$ W, 580 m, 08.IX.2011, fl., C.L.S.B. Correia et al. 558 (HUNEB); Trilha sentido sul da Estação ca. $8 \mathrm{~km}$ da Mata da Pororoca, 0942' $16^{\prime \prime}$ S and 38 29’31” W, 579 m, 08.IX.2011, fr., C.L.S.B. Correia et al. 571 (HUNEB).

Chamaecrista brevicalyx is endemic to Brazil, being distributed in Northern Minas Gerais and Northeastern Brazil in the states of Bahia, Pernambuco, Piauí and Paraíba. The species includes two varieties: C. brevicalyx (Benth.) H.S.Irwin \& Barneby var. brevicalyx and C. brevicalyx (Benth.) H.S.Irwin \& Barneby var. eliptica (H.S.Irwin \& Barneby) H.S.Irwin \& Barneby (Irwin $\&$ Barneby 1978). The distribution of the brevicalyx variety coincides with the species, while the eliptica variety occurs in Northern Bahia (Irwin \& Barneby 1978, Queiroz 2009). In the study area the species is represented only by the brevicalyx variety, which is very common. It was found with flowers in May to September and fruits from May to November.

In the study area the taxon can be clearly differentiated from the others by viscous branches, epidermis pale to whitish and exfoliate on the older branches and terminal, racemose inflorescences with axis 4-21 cm long.

5. Chamaecrista carobinha (H.S.Irwin \& Barneby) H.S.Irwin \& Barneby, Mem. New York Bot. Gard. 35: 661. 1982. Figures 2e; 5a-j

Herbs procumbent, sarmentose, little branched; branches cylindrical,erect to tortuous, epidermis green on the young branches, green-vinaceous on the old branches. Indumentum glabrescent, constituted of trichomes glandular and tector, thin, colourless to whitish and vinaceous to brown, flexible, erect and wavy, tangles, 0.5-1 mm long, distributed on the branches, pulvinus, petioles, stipules, rachis, leaflets, pedicels, bracts, bracteoles and sepals. Stipules green to green-vinaceous, filiform, obsolete, 2-4 $\times$ 0.5-1 mm long, persistent. Leaves $1.7-8.7 \mathrm{~cm}$ long; pulvinus green to vinaceous, pilose, $0.5-2 \mathrm{~mm}$ diam.; petiole $7-30 \mathrm{~mm}$ long, c. 1.5 times longer than the rachis; without extrafloral nectaries; rachis 4-20 mm long; leaflets discolorous, 2 pairs, chartaceous, puberulous, ovate to elliptic, $7-32 \times 5-24 \mathrm{~mm}$, apex rounded to emarginate, base asymmetrical to 


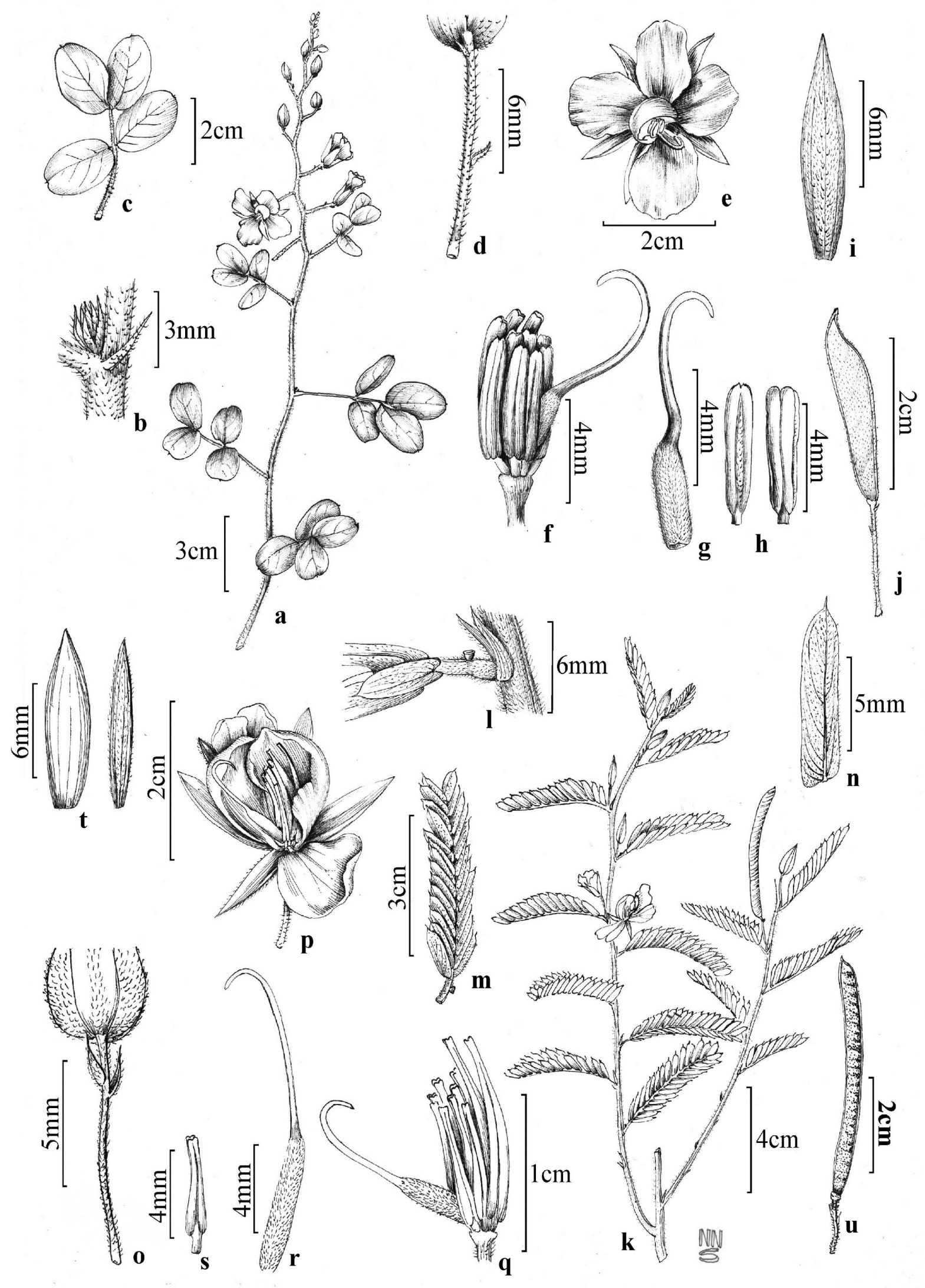

Figure 5. a-j) Chamaecrista carobinha: a) flowering branch; b) stipule; c) leaf; d) pedicel with bracteoles; e) flower; f) androecium and gynoecium; g) pistil; h. stamen; i) sepal; j) fruit. k-u) Chamaecrista nictitans var. disadena: k) flowering branch; 1) detail of stipule and extrafloral nectary; m) leaf; n) leaflet; o) pedicel with bracteoles; p) flower; q) androecium and gynoecium; r) pistil; s) stamen; t) sepal; u) fruit. a-j from C.L.S.B. Correia 498; k-u from C.L.S.B. Correia 160. 
rounded, venation penninervous. Inflorescences racemose, terminal, lax, 18-22 flowered; inflorescences axis 9-20 cm long; bracts green-vinaceous, filiform to lanceolate, $4-5 \times 0.5 \mathrm{~mm}$.; pedicel 4-16 mm long; bracteoles green, lanceolate to deltoid, $0.5-1 \times 0.5 \mathrm{~mm}$, located next to the receptacle. Buds green, acute, $2-11 \mathrm{~mm}$ long. Flowers c. $2.5 \mathrm{~cm}$ diam; sepals green to yellowish-green, lanceolate to ovate, abaxial surface pilose, striated, 5-9 $\times 2-3.5 \mathrm{~mm}$; petals yellow, two external, oblong, $2.5-3 \times 1-2.5 \mathrm{~mm}$, two internal, orbicular, $2-2.5 \times 1.5-2 \mathrm{~mm}$, cuculus falcate, bent around the stamens, $2.5-3 \times 1.5-2 \mathrm{~mm}$; stamens yellow to glaucos green, $3-5 \mathrm{~mm}$ long; ovary glaucous green, canescent, 1.5-2 mm long; style green to yellowish, 1-1.5 mm long. Legumes oblong, slightly curved, when young green, mature not seen, 26-29 × 5-6 mm; valves chartaceous, puberulous, sparsely setulose. Seeds not seen.

Material examined: BRAZIL, BAHIA: Paulo Afonso, Estação Ecológica Raso da Catarina, Trilha sentido casa II vindo da Mata da Pororoca, 0949'15" S and 38 29'33” W, 667 m, 08.VI.2011, fl., C.L.S.B. Correia et al. 484 (HUNEB); 01.VII. 2011, fl.; fr., C.L.S.B. Correia et al. 498 (HUNEB); 01.IX.2011, fl., C.L.S.B. Correia et al. 549 (HUNEB).

Chamaecrista carobinha is endemic to Caatinga and has been recorded from North Bahia and the South Piauí (Irwin \& Barneby 1978, Queiroz 2009). The species is rare in the study area and was collected in well-preserved areas with sandy soil at ca. $661 \mathrm{~m}$ with flowers in June, July and September and fruits in September.

The species can be easily recognized in the area by its herbaceous habit procumbent to sarmentose with two pairs of ovate to elliptic leaflets (7-32 $\times 5-24 \mathrm{~mm})$, and terminal, lax, racemose inflorescences, with axis 9-20 cm long.

6. Chamaecrista nictitans Moench subsp. disadena (Steud.) H.S.Irwin \& Barneby var. disadena (Steud.) H.S.Irwin \& Barneby, Mem. New York Bot. Gard. 35(2): 660. 1 (1982). Figures 2f; 5k-u

Herbs to subshrubs erect, little branched until $1 \mathrm{~m}$ tall; cylindrical branches,erect, epidermis green on the young branches, vinaceous on the old branches. Indumentum tomentose, constituted of trichomes tector, thin, blanks to colourless, flexible, erect and adpressed, slender, c. $0.5 \mathrm{~mm}$ long, distributed in the branches, petioles, stipules, rachis, leaflets, bracts, bracteoles, pedicels, buds and sepals. Stipules green to vinaceous, lanceolate, showy, 3-8 × 1-2 mm, persistent. Leaves 2.4-8.6 cm long; pulvinus brown, sparsely pilose, $1-2.5 \mathrm{~mm}$ diam.; petiole $6-8 \mathrm{~mm}$ long, equal or less than the rachis; 1 extrafloral nectary, vinaceous to brown, shortly stipitate, caliciform, $1-3 \mathrm{~mm}$ long, with head more dialated than the stipe, located next to the middle of the petiole; rachis 6-38 $\mathrm{mm}$ long; interfoliolar segments 1-4 mm long; leaflets discolorous, 18-21 pairs, chartaceous, pilose, oblong, 6-19 × 3-5 mm, apex acute, base cuneate, venation penninervous, midrib little excentric dividing the leaflet in a ratio of $1: 1-1.5$ at the base. Inflorescences fasciculate, supra-axillary, 2-5 flowered or reduced to a one flower; inflorescence axis $1.5-3.5 \mathrm{~cm}$ long; bracts green-vinaceous, lanceolate, $2-4 \times 1-1.5 \mathrm{~mm}$; pedicel $2-10.5 \mathrm{~mm}$ long; bracteoles green-vinaceous, lanceolate, $2-3 \times$ c. $1 \mathrm{~mm}$, located next to the middle of the pedicel. Buds green, acute, 5-15 mm long. Flowers c. $3 \mathrm{~cm}$ diam.; sepals green to yellowish-green, deltoid to lanceolate, the external pilose on the abaxial surface, internal glabrous, $13-16 \times 2-5 \mathrm{~mm}$; petals yellow to orange, two external, orbicular, $12-17 \times 6-13 \mathrm{~mm}$, two internal oblong, $11-12 \times 3-4 \mathrm{~mm}$, cuculus falcate, bent around the stamens, 12-14 × 8-9 mm; stamens yellow to yellowish-green, 6-15 mm long; ovary yellow, velutinous, 1-2 mm long; style light green to yellow, 13-15 mm long. Legumes oblong, linear, when young green to vinaceous, mature brown, 1.8-8.7 × 1-3 mm; valves chartaceous, glabrous to sparsely pilose. Seeds trapezoids, green-vinaceous, sparsely pitted, $1-1.5 \times 0.3-0.5 \mathrm{~mm}$.

Material examined: BRAZIL, BAHIA: Paulo Afonso, Estação Ecológica Raso da Catarina, Trilha sentido Mata da Pororoca, 948’32” S and 38²9’30 W, 584 m, 24.III.2010, fl.; fr., C.L.S.B. Correia et al. 99 (HUNEB); Trilha sentido Pedra da janela, $09^{\circ} 39^{\prime} 55^{\prime \prime} \mathrm{S}$ and $38^{\circ} 28^{\prime} 02^{\prime}$ ' W, 570 m, 01.VII.2010, fl.; fr., C.L.S.B. Correia et al. 160 (HUNEB); Trilha por trás da casa sede do ICMbio, 09³9.84.2" S and 38²8'0.06” W, $592 \mathrm{~m}$, 20.VIII.2010, fl.; fr., C.L.S.B. Correia et al. 218 (HUNEB); Trilha sentido Mata da Pororoca, vindo da casa I do ICMbio, 945'29" S and 38 29'29' W, 584 m, 29.XII.2010, fl., C.L.S.B. Correia et al. 343 (HUNEB); 29.XII.2010, fl., C.L.S.B. Correia et al. 367 (HUNEB); 14.I.2011, fl.; fr., C.L.S.B. Correia et al. 379 (HUNEB); 08.VI.2011, fl., C.L.S.B. Correia et al. 464 (HUNEB); Trilha sentido casa II, 0949'15” S and 38²9'33” W, 667 m, 08.VI.2011, fl.; fr., C.L.S.B. Correia et al. 468 (HUNEB); 01.IX.2011, fl.; fr., C.L.S.B. Correia et al. 551 (HUNEB); Trilha principal sentido Mata da Pororoca, 945'29' S and 38 29'29” W, 584 m, 08.VI.2011, fl., C.L.S.B. Correia et al. 481 (HUNEB); Trilha sentido Sul da Estação, ca. $10 \mathrm{~km}$ da Pororoca, 0943'18." S and 38²9'30” W, 580 m, 08.IX.2011, fl.; fr., C.L.S.B. Correia et al. 556 (HUNEB); 08.IX.2011, fl., C.L.S.B. Correia et al. 560 (HUNEB); 08.IX.2011, fl., C.L.S.B. Correia et al. 563 (HUNEB).

Chamaecrista nictitans is widely distributed in the Americas, occurring from the United States to Argentina, and includes four subspecies and 11 varieties, of which only disadena and pilosa occur in the Caatinga. In the study area, the species is represented by Chamaecrista nictitans var. disadena (Irwin \& Barneby 1982, Queiroz 2009). This taxon is quite common in the ESRC, and is found in more degraded areas on sandy-clayey soil at altitudes of 570 to $696 \mathrm{~m}$. It was collected with flowers and fruits from December to March and June to September.

In the study area, Chamaecrista nictitans subsp. disadena var. disadena resembles C. repens (Vogel) H.S.Irwin \& Barneby var. multijuga (Benth.) H.S.Irwin \& Barneby, with both possessing leaves with more than 15 pairs of leaflets and supra-axillary inflorescences. Nevertheless, Chamaecrista nictitans subsp. disadena var. disadena, can be differentiated by stipitate extrafloral nectaries with more dialated head than the stipe and leaflets with midrib slightly excentric in a ratio of 1:1-1.5 at the base (vs. robust extrafloral nectaries with head less dialated than the stipe and leaflets with midrib strongly excentric in a ratio of $1: 2-2.5$ at the base, in C. repens var. multijuga).

7. Chamaecrista ramosa (Vogel) H.S.Irwin \& Barneby var. ramosa, Mem New York Bot. Gard. 35(2): 884. 1982. Figure 6a-k

Subshrubs erect to procumbent, branched until $1 \mathrm{~m}$ tall; branches cylindrical, erect, epidermis vinaceous to purple on the young branches, brown on the old branches. Indumentum villous, constituted to trichomes tector, thin, blanks to brown, flexible, adpressed, sparse, c. $0.5 \mathrm{~mm}$ long, distributed on the branches, stipules, petioles, sepals and legumes. Stipules green, deltoid to cordiform, showy, 3-6 $\times 2-4 \mathrm{~mm}$, persistent. Leaves 7-15 cm long; pulvinus vinaceous, sparsely pilose, c. $8 \mathrm{~mm}$ diam.; petiole furrowed, 2-5 mm long; 1 extrafloral nectary, vinaceous to brown, stipitate, caliciform, c. $1 \mathrm{~mm}$ long, located on the petiole; rachis 0.5-1 mm long; leaflets discolorous, 2 pairs, chartaceous, pilose, obovate, 5-10 $\times 2-4 \mathrm{~mm}$, apex rounded, base cuneate to truncated; venation paralelinervous. Inflorescences axillary, reduced to a single flower; bracts vinaceous, lanceolate to deltoid, $1.5-3 \times 1-2.5 \mathrm{~mm}$; pedicel $12-26 \mathrm{~mm}$ long; bracteoles brown, ovate to deltoid, 0.5-2 $\times 1-2 \mathrm{~mm}$, located near the flower receptacle. Buds vinaceous, lanceolate, 9-14 mm long. Flowers c. $2 \mathrm{~cm}$ diam.; sepals green to green-vinaceous, lanceolate to elliptic or ovate to deltoid, abaxial surface pilose, multistriated, $5-11 \times 2.5-5 \mathrm{~mm}$; petals yellow, two external, spatulate to elliptic, 10-13.5 $\times 8-9 \mathrm{~mm}$, two internal, obovate to orbicular, 11-15 $\times 7-9 \mathrm{~mm}$, cuculus suborbicular to falcate, bent around the stamens, 13-14.5 $\times 20-23 \mathrm{~mm}$; stamens yellow, 4-8.5 mm long; ovary green glaucous, panoso, $6 \mathrm{~mm}$ long; style green, 4-6 mm long. Legumes oblong, linear, little incurved, when young vinaceous and mature castaneous glaucous, c. $30 \times$ c. $6 \mathrm{~mm}$; valves chartaceous, 


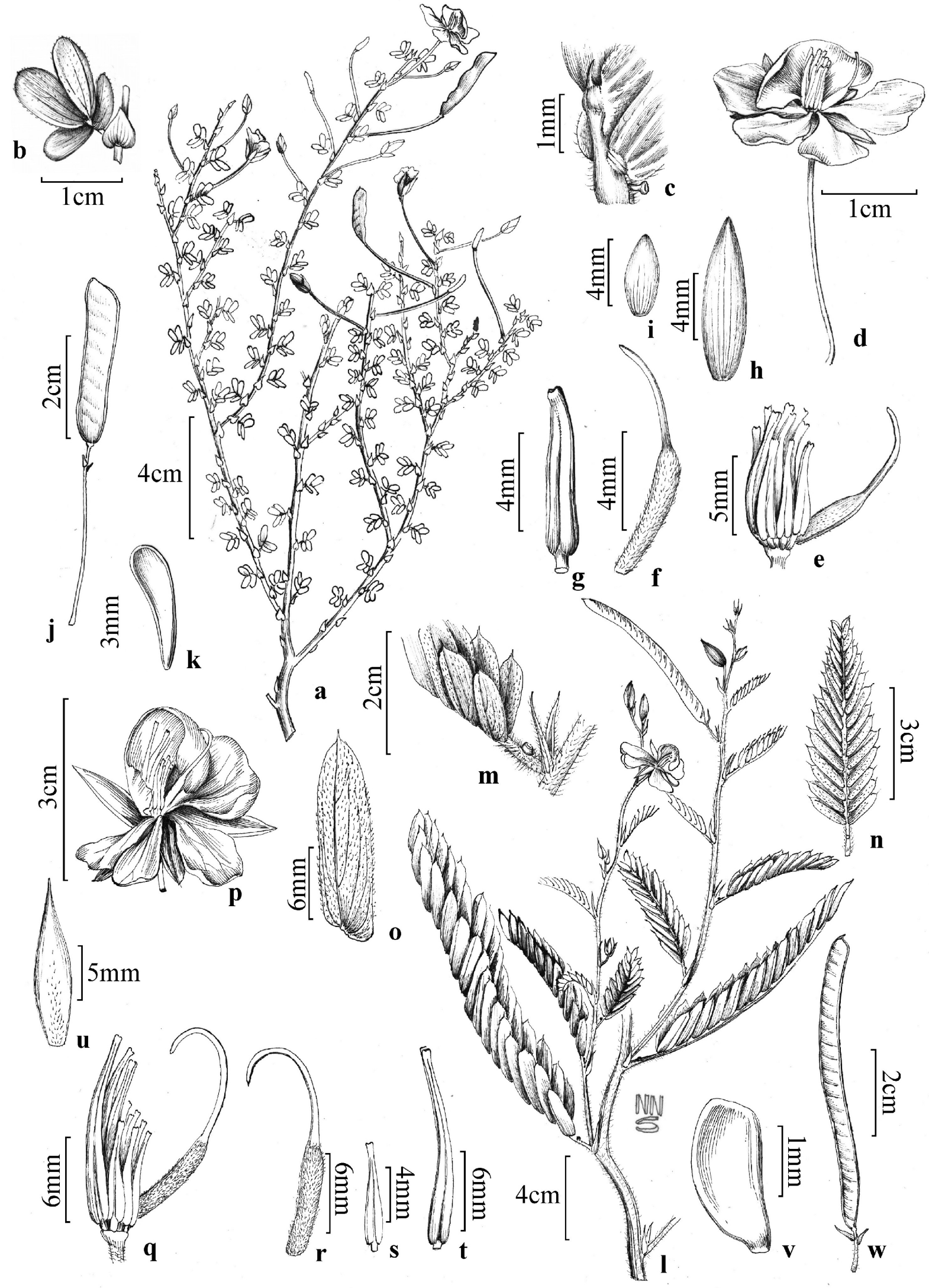

Figure 6. a-k) Chamaecrista ramosa var. ramosa: a) flowering branch; b) leaf; and stipule; c) detail of nectary; d) flower; e) androecium and gynoecium; f) pistil; g) stamen; h) external sepal; i) internal petal; j) fruit and pedicel with bracteoles; k) seed. 1-w) Chamaecrista repens var. multijuga: 1) flowering branch; m) detail of stipule and nectary; n) leaf; o) leaflet; p) flower; q) androecium and gynoecium; r) pistil; s) stamen; t) bigger stamen; u) sepal; v) seed; w) fruit and pedicel with bracteoles. a-k from C.L.S.B. Correia 570; 1-w from C.L.S.B. Correia 494. 
glabrous to puberulous. Seeds spatulated, brown, smooth and eventually pitted, 2-6 × 1.5-2 mm.

Material examined: BRAZIL, BAHIA: Paulo Afonso, Estação Ecológica Raso da Catarina, Trilha sentido sul da Estação, $8 \mathrm{~km}$ após a Mata da Pororoca, $09^{\circ} 42^{\prime} 16^{\prime \prime} \mathrm{S}$ and 38 29'31" W, 579 m, 08.IX.2011. fl.; fr., C.L.S.B. Correia et al. 561 (HUNEB); 08.IX.2011. fl.; fr., C.L.S.B. Correia et al. 570 (HUNEB).

The species occurs in South America and includes six varieties (Irwin \& Barneby 1982). This species is inserted in C. sect. Xerocalyx that possesses taxa with limits that are considered artificial. In 2005 based on morphological data Fernandes \& Nunes recognized only four varieties for the species. A biosystematic study of C. sect. Xerocalyx is in progress and should certainly help to more naturally delimit the taxa of this section. In the study area, the species is represented only by the ramosa variety, which is rare. This variety occurs from north South America to east Brazil (Irwin \& Barneby 1982, Queiroz 2009).

In the study area, the taxon can be easily recognized by erect procumbent to subshrub habit with leaves having 2 pairs of leaflets with paralelinervous venation and by isolated axillary flowers.

8. Chamaecrista repens (Vogel) H.S.Irwin \& Barneby var. multijuga (Benth.) H.S.Irwin \& Barneby, Mem. New York Bot. Gard. 35(2): 660. 1982. Figures 2g; 61-w

Subshrubs erect, branched until $1.5 \mathrm{~m}$ tall; branches cylindrical, erect, epidermis green on the young branches, vinaceous on the old branches. Indumentum vilosous, constituted to trichomes tector, thin, blanks to colourless, flexible, erect and adpressed, slender, c. $1 \mathrm{~mm}$ long, distributed on the branches, pulvinus, stipules, petioles, rachis, leaflets, bracts, bracteoles, buds, pedicels, sepals and young legumes. Stipules green to green-vinaceous, lanceolate, little showy, 6-8 $\times 0.5-1 \mathrm{~mm}$, persistent. Leaves 1.6-12.1 cm long; pulvinus black, pilose, 1-2 mm diam.; petiole furrowed, 6-14 mm long; 1 extrafloral nectary, vinaceous to brown, sessile to shortly stipitate, discoid to caliciform, c. $1 \mathrm{~mm}$ long, head less dilated than stipe, located little above the middle of the petiole; rachis $8-113 \mathrm{~mm}$ long; interfoliolar segments 1-4 mm long; leaflets discolorous, 8-17 pairs, chartaceous, pilose, 6-21 $\times 1-7 \mathrm{~mm}$, oblong, apex cuspidate, mucronate, base truncated, venation palminerveous, midrib little excentric dividing the leaflet in a ratio of 1:2-2.5 at the base. Inflorescences fasciculate, supra-axillary, 5 flowered or reduced to a single flower; pedicel $1.5-3.5 \mathrm{~cm}$ long; bracts green-vinaceous, lanceolate, $2-4 \times 1-1.5 \mathrm{~mm}$; bracteoles green-vinaceous, lanceolate, $2-3 \times$ c. $1 \mathrm{~mm}$, located next to the receptacle. Buds green, lanceolate, 5-15 mm long. Flowers c. $3 \mathrm{~cm}$ diam.; sepals green to yellowish-green, deltoids to elliptical, abaxial surface pilose, striated, 15-18 $\times 3-6 \mathrm{~mm}$; petals yellow to orange, one external, orbicular, c. $22 \times 21 \mathrm{~mm}$, three internal, oblong, 11-17 ×6-7 mm, cuculus falcate, assimetric, bent around the stamens, 18-20 × 19-22 mm; stamens yellow to yellowish-green, 5-16 mm long; ovary yellow, tomentose, $8-9 \mathrm{~mm}$ long; style glaucous green to yellow, 6-8 mm long. Legumes oblong, linear, pilose, when young vinaceous, mature brown, 38-76 × 2-4 mm; valves chartaceous, sparsely puberulous. Seeds trapezoids, brown, pitted, $2-3.5 \times 1-4 \mathrm{~mm}$.

Material examined: BRAZIL, BAHIA: Paulo Afonso, Estação Ecológica Raso da Catarina, Trilha sentido Baixa da onça, 0952'21” S and 38 37' $88^{\prime \prime}$ ' W, 521 m, 29.VI.2010. fl.; fr., C.L.S.B. Correia et al. 129 (HUNEB); Casa sede do ICMbio, 09³9.84" S and 38 $28^{\circ}$ '06" W, $592 \mathrm{~m}$, 06.V.2011, fl.; fr., R.R. Varjão et al. 99 (HUNEB); 01.VII.2011, fl.; fr., C.L.S.B. Correia et al. 492 (HUNEB); 01.VII.2011, fl.;fr., C.L.S.B. Correia et al. 494 (HUNEB); 01.VII.2011, fl.;fr., C.L.S.B. Correia et al. 496 (HUNEB); 27.VII.2011, fl.; fr., C.L.S.B. Correia et al. 519 (HUNEB); Trilha principal próximo a casa do Sr. Divá, 0948'33" S and 38²9'31" W, 614 m, 27.VII.2011. fl., C.L.S.B. Correia et al. 530 (HUNEB); Trilha para cara feia próximo ao curral do dentinho, 0947'29" S and 38³0’31" W, 588 m, 31.VIII.2011. fl., C.L.S.B. Correia et al. 537 (HUNEB).

Chamaecrista repens was reported by Irwin \& Barneby (1982), as endemic to South American with two varieties: C. repens var. multijuga and $C$. repens var. repens. Of these two varieties, only multijuga occurs in the Caatinga, and is distributed in the Northeastern Region of Brazil to Minas Gerais (Irwin \& Barneby 1982, Queiroz 2009). In the study area, C. repens var. multijuga is very common, occurring in anthropized areas on sandy-clayey soil at altitudes of 406 to $592 \mathrm{~m}$. Flowers and fruits were recorded from May to August.

The taxon can be recognized in the study area by leaves with $8-17$ pairs of leaflets, with the midrib extremely excentric in ratio of ca. 1:2-2.5 at the base and by inflorescence fasiculate, supra-axillary, with up to five flowers or reduced to a single flower. Chamaecrista repens var. multijuga can be confused with $C$. nictitans var. disadena, because both possess leaves with more than 8 pairs of leaflets and supra-axillary inflorescences. However, the two taxa can be differentiated by morphology of the extrafloral nectary and the position of the midrib of the leaflets, as mentioned in C. nictitans var. disadena.

9. Chamaecrista swainsonii (Benth.) H.S.Irwin \& Barneby, Mem. New York Bot. Gard. 35(2): 701.1982. Figures 2h; 7a-k

Subshrubs erect, little branched until $0.6 \mathrm{~m}$ tall; branches quadrangular, fractiflex, epidermis green on the young branches, vinaceous to brown on the old branches. Indumentum vilosous, constituted by trichomes tector, thin, whitish, flexible, erect, sparse, c. $0.5 \mathrm{~mm}$ long, distributed on the branches, stipules, petioles, rachis, leaflets, bracts, bracteoles, pedicels, sepals and legumes. Stipules green speckled green purple on the base, past brown, acuminate to aristate, venation prominent on face adaxial, extremely showy, 4-14 × 5-17 mm, persistent. Leaves $2.4-6.2 \mathrm{~cm}$ long; pulvinus brown, glabrous, c. $1 \mathrm{~mm}$ diam; petiole furrowed, $2-13 \mathrm{~mm}$ long, c. 7 times greater than the rachis; $2-9$ extrafloral nectary, green glaucous, stipitate, caliciform, located on petiole and on the rachis, one each interfoliolar segments, $0,4-1,0 \mathrm{~mm}$ long; rachis grooved, carrying a nectary, 14-42 mm long; interfoliolar segments 2-6 mm long; leaflets discolorous, 4-8 pairs, coriaceous, pubescent, $8-24 \times 2.1-8.3 \mathrm{~mm}$, oblong, apex cuspidate to spinescent, base rounded, venation palminerveous, prominent. Inflorescences axillary, reduced to a single flower; bracts green, purple speckled on the base, past brown, lanceolate to elliptical, $4-5 \times$ c. $0.5 \mathrm{~mm}$; pedicel 24-34 mm long; bracteoles green to green-vinaceous, elliptical to lanceolate, $1-3.5 \times$ c. $0.5 \mathrm{~mm}$, located above the middle of the pedicel. Buds green to yellowish-green, ovate to lanceolate, 9-14 mm long. Flowers c. $2 \mathrm{~cm}$ diam.; sepals green to yellowish-green, sparsely pilose, striated, lanceolate to deltoid, $1-14 \times 3-8 \mathrm{~mm}$; petals yellow glaucous to orange, two external, oblong to orbicular, $8-13.5 \times 6-9.5 \mathrm{~mm}$, two internal, spatulate to ovate, $10-11.5 \times$ c. $5.5 \mathrm{~mm}$, cuculus oblong to falcate, bent around the stamens, $11-13.5 \times 10-11.5 \mathrm{~mm}$; stamens yellow, 4-8.5 mm long; ovary green, tomentose, $4 \mathrm{~mm}$ long; style green, 4-5.5 mm long. Legumes oblong-linear, linear, pilose, green to green-vinaceous when young, mature brown, 12-47 × 2-6 mm; valves chartaceous, harsh. Seeds quadrangular to trapezoid, castaneous, pitted, 3-4 × 2.5-3 mm.

Material examined: BRAZIL, BAHIA: Paulo Afonso, Estação Ecológica Raso da Catarina Trilha sentido Pororoca, 945'29' S and 38²9'29” W, 584 m, 24.III.2010, fr., C.L.S.B. et al. 102 (HUNEB); 19.V.2010, fr., M.V.V. Romão et al. 608 (HUNEB); 19.V.2010, fr., M.V.V. Romão et al. 616 (HUNEB); Trilha sentido Pedra da janela, 09³9'55" S and 38²8'02” W, 570 m 30.VI.2010, fl.; fr., R.R.O. Lima et al. 06 (HUNEB); 30.XII.2010, fl., C.L.S.B. Correia et al. 360 (HUNEB); 25.VII.2011, fl., C.L.S.B. Correia et al. 503 (HUNEB); Trilha sentido casa II, vindo da Pororoca, 0949'15” S and 38²9'33” W, 667 m, 14.I.2011, fl., C.L.S.B. Correia et al. 370 (HUNEB); 04.II.2011, fr., C.L.S.B. Correia et al. 390 


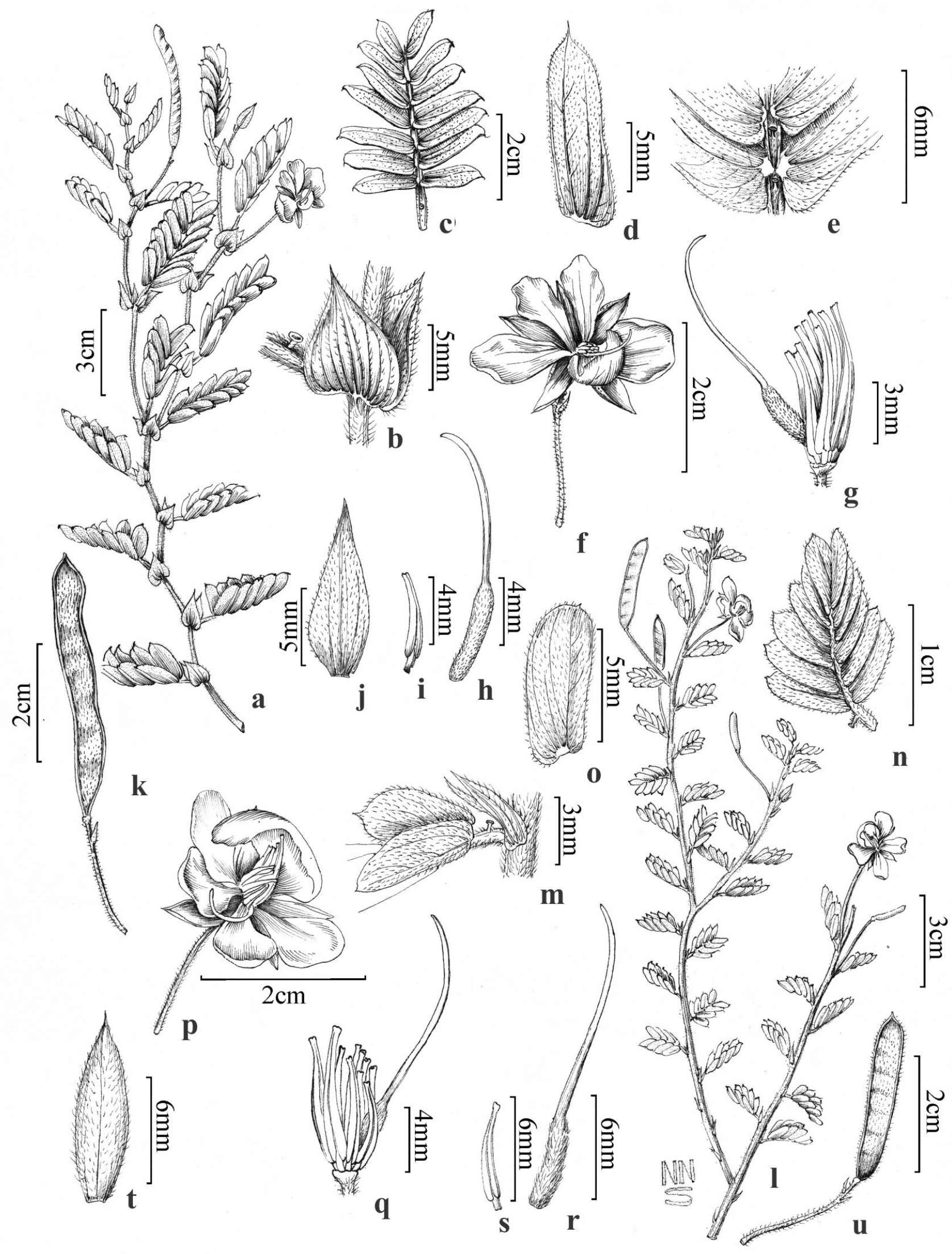

Figure 7. a-k) Chamaecrista swainsonii: a) flowering branch; b) stipule; c) leaf; d) leaflet; e) location of extrafloral nectary; f) flower; g) androecium and gynoecium; h) pistil; i) stamen; j) sepal; k) fruit and pedicel with bracteoles. 1-u) Chamaecrista tenuisepala: 1) flowering branch; m) detail of stipule and nectary; n) leaf; o) leaflet; p) flower; q) androecium and gynoecium; r) pistil; s) stamen; t) sepal; u) fruit and pedicel with bracteoles. a-k from C.L.S.B. Correia 390; 1-u from C.L.S.B. Correia 548. 
(HUNEB); 04.V.2011, fl., C.L.S.B. Correia et al. 448 (HUNEB); 08.VI.2011, fr., C.L.S.B. Correia et al. 483 (HUNEB); 01.IX.2011, fl.; fr., C.L.S.B. Correia et al. 550 (HUNEB); Trilha principal antes da Pororoca vindo da casa base, 09³9'54.8' S and 38²7'59.8” W, 618 m, 27.IX.2011, fl.; fr., C.L.S.B. Correia et al. 586 (HUNEB).

Chamaecrista swainsonii is endemic to Bahia and occurs in Caatinga, Cerrado and Restinga (Irwin \& Barneby 1982, Queiroz 2009). According to Queiroz (2009), in the Caatinga the species occurs at altitudes of 680 to $1000 \mathrm{~m}$. In the ESRC the species is common and was collected on sandy, sandy-clayey and rocky soils with flowers in December to June and fruiting from January to June.

It is characterized in the study area by the presence of quadrangular, fractiflex branches; acuminate to aristate stipules with prominent nervure, and leaves with 4-8 pairs of coriaceous, oblong leaflets with cuspidate to spinescent apex and palminerveous prominent venation.

10. Chamaecrista tenuisepala (Benth.) H.S.Irwin \& Barneby, Mem. New York Bot. Gard. 35: 707. 1982. Figures 2i; 71-u

Subshrub erect, little branched until $1 \mathrm{~m}$ tall; cylindrical branches, erect, little striated, not exfoliating, epidermis vinaceous to brown on the braches young and old. Indumentum tomentose, constituted by trichomes tector, thin, whitish, flexible, erect and wavy, tangles, c. $0.5 \mathrm{~mm}$ long, distributed on the branches, pulvinus, stipules, petioles, rachis, leaflets, pedicels, bracts, bracteoles, sepals, ovary and legumes. Stipules green to green-vinaceous, past brown, lanceolate to deltoid, obsolet, $1-7 \times 1-2 \mathrm{~mm}$, persistent. Leaves 1-3 cm long; pulvinus green, pilose, $0.5-1 \mathrm{~mm}$ diam.; petiole 2-4 mm long; 1 extrafloral nectary, brown to green-vinaceous, stipitate, caliciform, located on petiole, below pair of proximal leaflets, $1-1.5 \mathrm{~mm}$ long; rachis 5-20 mm long; interfoliolar segments $1-3 \mathrm{~mm}$ long; leaflets discolorous, 5-6 pairs, chartaceous, pubescent with greater intensity on the face adaxial, $3-13 \times 2-4 \mathrm{~mm}$, oblong, apex acuminate to cuspidate, base asymmetrical, venation palminerveous. Inflorescences axillary, reduced to a single flower; bracts green-vinaceous, lanceolate to deltoids, $4-5 \times$ c. $0.5 \mathrm{~mm}$; pedicel $12-36 \mathrm{~mm}$ long; bracteoles green, lanceolate, 3-4 × c. $0.5 \mathrm{~mm}$, located along the pedicel. Buds green to yellowish-green, lanceolate to ovate, $7-15 \mathrm{~mm}$ long. Flowers c. $1.5 \mathrm{~cm}$ diam.; sepals green to yellowish-green, lanceolate to deltoid, abaxial surface pilose, striated, 6-12 × 2-4 mm; petals yellow glaucous, two external, obovate, $13-18 \times 8-11 \mathrm{~mm}$, two internal, spatulate, $11-14 \times 7-10 \mathrm{~mm}$, cuculus falcate, bent around the stamens, $12-16 \times 13-17 \mathrm{~mm}$; stamens yellow, 3.5-11 mm long; ovary green glaucous to whitish, tomentose, 4-7 mm long; style green glaucous, 5-11 mm long. Legumes oblong, linear, green-vinaceous when young, mature brown, 9-42 × 2-6.5 mm; valves chartaceous, pilose, setulose. Seeds trapezoid, brown, pitted at base, $2-2.5 \times$ c. $1 \mathrm{~mm}$.

Material examined: BRAZIL, BAHIA: Paulo Afonso, Estação Ecológica Raso da Catarina, Trilha sentido Pedra da coruja, 09³9'55.9” S and $38^{\circ} 28^{\prime} 02.5^{\prime \prime} \mathrm{W}$ 01.VII.2010. fl.; fr., C.L.S.B. Correia et al. 157

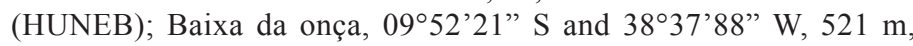
24.III.2010. fl.; fr., C.L.S.B. Correia et al. 104 (HUNEB); Trilha sentido Mata da Pororoca. 948'32" S and 38 $29^{\prime} 30$ W, 584 m, 24.III.2010. fl.; fr., C.L.S.B. Correia et al. 101 (HUNEB); 29.XII.2010. fl.; fr., C.L.S.B. Correia et al. 340 (HUNEB); 29.XII.2010. fl.;fr., C.L.S.B. Correia et al. 342 (HUNEB); Trilha sentido Mata da Pororoca vindo da casa I, depois da $1^{\circ}$ encruzilhada $9^{\circ} 47^{\prime} 57^{\prime \prime} \mathrm{S}$ and $38^{\circ} 29^{\prime} 30^{\prime \prime} \mathrm{W}, 584 \mathrm{~m}, 04 . I I .11$. fl., C.L.S.B. Correia et al. 384 (HUNEB); Trilha do Transecto UFRVB, próximo a casa base do ICMbio, $9^{\circ} 48^{\prime} 50^{\prime \prime} \mathrm{S}$ and $38^{\circ} 28^{\prime} 01^{\prime \prime} \mathrm{W}, 560 \mathrm{~m}$, 17.VIII.2010. fl.; fr., C.L.S.B. Correia et al. 187 (HUNEB); 29.XII.2010. fl.; fr., C.L.S.B. Correia et al. 366 (HUNEB); Trilha sentido casa II vindo da Mata da Pororoca, 0949'15" S and 38²9'33" W, 667 m, 04.II.11. fl.; fr., C.L.S.B. Correia et al. 388 (HUNEB); 04.IV.11. fl., C.L.S.B. Correia et al. 429 (HUNEB); 08.VI.11. fl., C.L.S.B. Correia et al. 463 (HUNEB); 24.XI.11. fl.; fr., C.L.S.B. Correia et al. 280 (HUNEB).
The species is endemic to northeastern Brazil, having been recorded to southern Maranhão and Piauí to western Pernambuco and Paraíba (Irwin \& Barneby 1982, Queiroz 2009). In the study area, Chamaecrista tenuisepala is very common and occurs on sandy, sandy-clayey and rocky soils at altitudes of 520 to $667 \mathrm{~m}$. It was collected with flowers and fruits nearly every month of the year.

Chamaecrista tenuisepala can be recognized in the area by subshrub habit, lanceolated to deltate stipules, stipitate and caliciform extrafloral nectary located on the petiole below the pair of proximal leaflets, leaves with 5-6 pairs of leaflets and isolated axillary flowers of ca. $1.5 \mathrm{~cm}$ in diam.

\section{Supplementary material}

The following online material is available for this article:

Appendix: List of additional material examined

\section{Acknowledgements}

Thanks to the Fundação de Amparo à Pesquisa do Estado da Bahia (FAPESB, PET \#0023 /2007) and to the Conselho Nacional de Desenvolvimento Científico e Tecnológico (CNPq Proc. \#552589/2011-0) for financial support. To Instituto Chico Mendes (ICMBio) for their support during field work. To anonymous reviewer by improvements. The first author thanks the Coordenação de Aperfeiçoamento de Pessoal de Nível Superior (CAPES) by scholarship, the curators and technicians of the herbaria that were visited for their readiness during the consultation of the collections and Natanael Santos for the botanical illustrations.

\section{Author Contributions}

Cláudia Letícia de Souza Barros Correia: Contribution to the acquisition of data; analysis and interpretation of data; work of writing and conception and design work.

Adilva de Souza Conceição: Contribution to the acquisition of data; analysis and interpretation of data; work of writing; critical review adding intellectual content and conception and design work.

\section{Conflicts of interest}

The authors declare that they have no conflict of interest related to the publication of this manuscript.

\section{References}

BARBOSA, A.R.; MACHADO, M.C.; LEWIS, G.P.; FOREST, F. \& QUEIROZ L. P. 2016. Re-establishment of Chamaecrista cultrifolia (Leguminosae, Caesalpinioideae) based on morphological and molecular analyses. Phytotaxa 265(3):183-203.

BARNEBY, R.C. 1994. A new species of Chamaecrista Moench (Caesalpiniaceae) from interior Bahia, Brazil. Brittonia 46:69-71.

BENTHAM, G. 1870. Cassia. In Flora Brasiliensis (C.F.P. Martius, A.G. Eichler \& I. Urban, eds) F. Fleischer, Lipsiae, v.15, p.82-176.

BENTHAM, G. 1871. Revision of the genus Cassia. Transactions of the Linneaum Society of London 27:503-59.

BORTOLUZZI, R.L.C. \& MIOTTO, S.T.S. 2007. Novos registros de Chamaecrista Moench e Senna Mill (Leguminosae, Caesalpinioideae) na flora sul-brasileira. Iheringia, Série Botânica 62:123-132.

BRITTON, N.L. \& ROSE, J.N. 1930. The family Caesalpiniaceae, genus Cercis. North American Flora 23:201- 202.

CAMARGO, R.A \& MIOTTO, S.T.S. 2004. O gênero Chamaecrista Moench (Leguminosae-Caesalpinioideae) no Rio Grande do Sul. Iheringia, Série Botânica 59:131-148. 
CARDOSO, D.B.O.S. \& QUEIROZ, L.P. 2007. Diversidade de Leguminosae nas caatingas de Tucano, Bahia: Implicações para a fitogeografia do semiárido do Nordeste do Brasil. Rodriguésia 58:379-391.

CONCEIÇÃO, A.S. 2006. Filogenia do gênero Chamaecrista (LeguminosaeCaesalpinioideae) e taxonomia do grupo Baseophyllum. Tese de doutorado, Universidade Estadual de Feira de Santana, Feira de Santana.

CONCEIÇÃO, A.S., GIULIETTI, A.M. \& LEWIS, G.P. 2001. Novas Espécies de Chamaecrista Moench (Leguminosae-Caesalpinioideae) da Chapada Diamantina, Bahia, Brasil. Sitientibus 1:102-119.

CONCEIÇÃO, A.S., GIULIETTI, A.M. \& QUEIROZ, L.P. 2003. O gênero Chamaecrista Moench (Leguminosae-Caesalpinioideae) em Catolés, Abaíra, Chapada Diamantina, Bahia. Brasil. Sitientibus 3:81-108.

CONCEIÇÃO, A.S., QUEIROZ, L.P., LEWIS, G.P., ANDRADE M.J.G., ALMEIDA, P.R.M., SCHNADELBACH, A.S. \& VAN DEN BERG, C. 2009. Phylogeny of Chamaecrista Moench (Leguminosae-Caesalpinioideae) based on nuclear and chloroplast DNA regions. Taxon 58:1168-1180.

COSTA, C.R.A. 1996. Estudo taxônomico de Chamaecrista Moench. (LeguminosaeCaesalpinioideae), ocorrente no litoral de Pernambuco. Dissertação de mestrado, Universidade Federal de Pernambuco, Recife.

COTA, M.M.T., RANDO, J.G. \& MELLO-SILVA, R. 2016. Chamaecrista petiolata (Leguminosae, Caesalpinioideae), new species from Diamantina Plateau, Minas Gerais, Brazil. Phytotaxa 267:70-76.

DANTAS, M.M. \& SILVA, M.J. 2013. O gênero Chamaecrista (Leguminosae, Caesalpinioideae, Cassieae) no Parque Estadual da Serra Dourada, Goiás, Brasil. Rodriguésia 64:581-595.

FERNADES, A. \& NUNES, E.P. 2005. Reformulação taxonômica de Chamaecrista: seção Xerocalyx (Benth.) Irwin \& Barneby. In Registros Botânicos (A. Fernandes $\&$ E. P. Nunes, ed.). Livro técnico, Fortaleza.

FOSBERG, F.R. \& SACHET, M.H. 1965. Manual for tropical herbaria. Utrecht, Netherlands.

GONÇALVES, E.G \& LORENZI, H. 2011. Morfologia Vegetal: Organografia e dicionário ilustrado de morfologia das plantas vasculares. 2 ed. Instituto Plantarum de Estudos da Flora, Nova Odessa, São Paulo.

GREENE, E.L. 1897. The genus Chamaecrista. Pittonia 3:238-243.

HARLEY, R.M. \& SIMMONS, N.A. 1986. Florula of Mucugê. Chapada Diamantina, Bahia, Brazil. Royal Botanic Gardens, Kew.

HARRIS, J. \& HARRIS, M. 2001. Plant identification terminology: an illustrated glossary. 2 ed. Spring lake publishing, Utah.

HERVENCIO, P. \& QUEIROZ, L.P. 2004. A new species of Chamaecrista sect. Absus (Leguminosae-Caesalpinioideae) from Minas Gerais, Brazil. Kew Bulletin 59:149-151.

IRWIN, H.S. 1964. Monographic studies in Cassia (Legumionsae-Caesalpinioideae). I. Section Xerocalyx. Memoirs of the New York Botanical Garden 12(1):1-114.

IRWIN, H.S. \& BARNEBY, R.C. 1977. Monographic studies in Cassia (LeguminosaeCaesalpinioideae). Suplementary notes on section Apoucouita Bentham. Brittonia 29:277-290.

IRWIN, H.S. \& BARNEBY, R.C. 1978. Monographic studies in Cassia (Leguminosae Caesalpinioideae). III. Sections Absus and Grimaldia. Memoirs of the New York Botanical Garden 30:1-300.

IRWIN, H.S. \& BARNEBY, R.C. 1981. Cassieae. In Advances in legume Systematicas. (R.M. Polhill \& P.H. Raven, eds.). Royal Botanical Garden, Kew, p.97-106.

IRWIN, H.S. \& BARNEBY, R.C. 1982. The American Cassiinae, a synoptical revision of Leguminosae tribe Cassieae subtribe Cassiinae in the World. Memoirs of The New York Botanical Garden 35: 1-918.

IRWIN, H.S. \& ROGERS, D.J. 1967. Monographic studies in Cassia (LegumionsaeCaesalpinioideae). II. A taximetric study of section Apoucouita. Memoirs of the New York Botanical Garden 16:71-120.

LEWIS, G.P. 1987. Legumes of Bahia. Royal Botanic Gardens, Kew.

LEWIS, G.P. 2005. Tribe Cassieae. In Legumes of the World. (G.P. Lewis, B. Schrire, B. Mackinder \& M. Lock, eds.) Royal Botanical Garden, Kew, p.111-161.

MOENCH, K. 1794. Methodus Plantas Horti Botaniciet Agri Marburgensis: astaminum situ describendi. Marbugi Cattorum.

MORI, S.A.; SILVA, A.M.; LISBOA, A. \& CORADIN, L. 1989. Manual de manejo de herbário fanerogâmico. 2 ed. Centro de pesquisas do Cacau, Itabuna.

POLLARD, C.L. 1902. The genus Chamaecrista. Proceedings of the Biological Society of Washington, Washington.
QUEIROZ, L.P. 2009. Leguminosas da Caatinga. Universidade Estadual de Feira de Santana, Feira de Santana.

QUEIROZ, R.T. \& LOIOLA, M.I.B. 2009. O gênero Chamaecrista Moench. (Caesalpinioideae) em áreas do entorno do Parque Estadual das Dunas de Natal, RN, Brasil. Hoehnea 36:725-736.

RANDO, J.G. \& PIRANI, J.R. 2012. A new species of Chamaecrista sect. Chamaecrista ser. Flexuosae (Leguminosae, Caesalpinioideae) from Serra do Cipó, Minas Gerais, Brazil. Brittonia 64:241-245.

RANDO, J.G. 2009. Chamaecrista Monch seções Apoucoita, Chamaecrista e Xerocalix (Leguminosae-Caesalpinioideae) na Serra do Cipó, Minas Gerais, Brasil. Dissertação de Mestrado, Universidade de São Paulo, São Paulo.

RANDO, J.G., HERVENCIO, P., SOUZA, V.C., GIULIETTI, A.M. \& PIRANI, J.R. 2013a. Flora da Serra do Cipó Minas Gerais: Leguminosae - "Caesalpinioideae". Boletim de botânica da Universidade de São Paulo. 31 (2): 141-198.

RANDO, J.G., LOEUILLE, B. \& PIRANI, J.R. 2013b. Taxonomic novelties in Chamaecrista (Leguminosae: Caesalpinioideae) from Brazil. Phytotaxa 97:17-25.

RANDO, J.G., ZUNTINI, A.R., CONCEIÇÃO, A.S., VAN DEN BERG, C., PIRANI, J.R. \& QUEIROZ, L.P. 2016. Phylogeny of Chamaecrista ser. Coriaceae (Leguminosae) Unveils a Lineage Recently Diversified in Brazilian Campo Rupestre Vegetation. International Journal of Plant Sciences 177:3-17.

RIBEIRO, J.E.L.S.; HOPKINS, M.J.; VICENTINI, A.; SOTHERS, C.; COSTA, M.A.S.; BRITO, J.M.; SOUZA, M.A.; MARTINS, L.H.; LOHMANN, L.; ASSUNÇÃO, P.A.; PEREIRA, E.C.; SILVA, C.F.; MESQUITA, M.R. \& PROCÓPIO, L.C. 1999. Flora da Reserva Ducke: guia de identificação das plantas vasculares de uma floresta de terra-firme na Amazônia Central. INPA, Manaus.

SAMPAIO, E.V.S.B. \& RODAL, M.J.N.A. 2002. Vegetação do bioma Caatinga. In Vegetação e flora das Caatingas (E.V.S.B. Sampaio, ed.) APNE/CNIP, Recife, p. 11-24.

SILVA, M.J. \& SOUZA, A.O. 2014. A new species of the genus Chamaecrista (Leguminosae, Caesalpinioideae) from Chapada dos Veadeiros, Goiás, Brazil. Phytotaxa 174 (3):181-186.

SOUZA, A.O. \& SILVA, M.J. 2015. A new species of Chamaecrista (Leguminosae) from the Brazilian Central Plateau. Phytotaxa 204 (2):165-171.

SOUZA, A.O \& SILVA, M.J. 2015. What's new in Chamaecrista (Fabaceae, Caesalpinioideae) from the Brazilian Cerrado? Phytotaxa 213(3):253-262.

SOUZA, A.O, SILVA, M.J. \& ALONSO, A.A. 2015. Novelties in Chamaecrista (Fabaceae, Caesalpinioideae) from the Brazilian Cerrado. Phytotaxa 239(2):143-154.

SOUZA, V.C. \& BORTOLUZZI, R.L.C. 2016. Chamaecrista. In Lista de Espécies da Flora do Brasil. (R.C. Forzza, A. Costa, B.M.T. Walter, J.R. Pirani, M.P. Morim, L.P. Queiroz, G. Martinelli, A.L. Peixoto, M.A.N. Coelho, J.F.A. Baumgratz, J.R. Stehmann, L.G. Lohmann, eds.) Jardim Botânico do Rio de Janeiro. Available in: <http://floradobrasil.jbrj.gov.br/jabot/floradobrasil/ FB22876> (last access in 13 June 2016)

SZABO, A.V., ROCHA, A.C.S., TOSATO, J.A.C. \& BARROSO, W. 2007. Área de proteção ambiental (APA) Serra Branca Raso da Catarina. In As caatingas: debates sobre a Ecorregião do Raso da Catarina (J. Marques, org.). Fonte Viva, Paulo Afonso, p. 21-40.

TRICART, J. 1972. The landforms of the humid tropics, forests and savannas. Geographies for Advanced Study, Longman, London.

VARJÃO, R.R., JARDIM, J.G. \& CONCEIÇÃO, A.S. 2013. Rubiaceae Juss. of caatinga of the APA Serra Branca/ Raso da Catarina, Bahia, Brazil. Biota Neotrop. 13(2): 105-123. http://www.biotaneotropica.org.br/v13n2/en/abstract ?inventory+bn00313022013 (last access on 26 June 2016)

VELLOSO, A.L.; SAMPAIO, E.V.S.B. \& PAREYN, F.G.C. 2002. Ecorregiões propostas para o Bioma Caatinga. Flamar Gráfica e Editora, Recife.

VOGEL, T. 1837. Synopsis generis Cassiae. Académie des Sciences, Paris.

ZAPPI, D.C., LUCAS, E., STANNARD, B., LUGHADA, E.N., PIRANI, J.R., QUEIROZ, L.P., ATKINS, S., HIND, D.J.N., GIULIETTI, A.M. \& HARLEY, R.M. 2003. Lista das plantas vasculares de Catolés, Chapada Diamantina, Bahia, Brasil. Boletim de Botânica (USP) 21:345-398.

Received: 27/06/2016

Revised: 07/03/2017

Accepted: 19/03/2017

Published online: 27/04/2017 